\title{
The Anglo-French Continental Shelf Case
}

\author{
E.D. BROWN*
}

The Anglo-French Case (1977-1978) is only the second continental shelf boundary dispute to have been settled by judicial means and the first between parties to the 1958 Geneva Convention on the Continental Shelf. Recognising the decisions of the Court of Arbitration as an important landmark in the development of continental shelf law, Professor Brown presents a detailed analysis and assessment of the court's decisions in the light of the earlier judgment of the International Court of Justice in the North Sea Continental Shelf Cases (1969) and the continuing negotiations in UNCLOS III.

I. InTRODUCTTON $\ldots \ldots \ldots \ldots \ldots \ldots \ldots \ldots \ldots \ldots \ldots \ldots, 463$

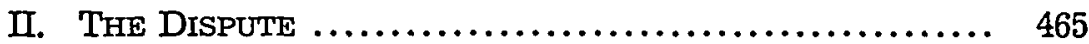

III. ThE APPLICABLE LAW ........................ 467

A. The Relationship of Article 6 to International Customary Law ................................ 468

IV. The Boundary Lines ............................ 470

A. The Area of Narrow Waters Between the Channel Islands Archipelago and the Coasts of Normandy and Brittany ............................... 470

B. The Area Ultimately Delimited by the Line A-D .. 470

C. The Areas Ultimately Delimited by the Lines $E-F$

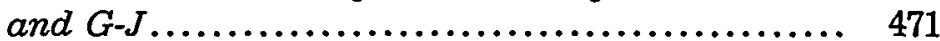

D. The Channel Islands Sector................ 471

*Professor of International Law, University of Wales; Director, Centre for Marine Law and Policy, University of Wales Institute of Science and Technology, Cardiff, United Kingdom. B.L., University of Edinburgh, 1957; LL.M., 1964; Ph.D., University of London, 1970.

April 1979 Vol. 16 No. 3 
E. The Area Ultimately Delimited by the Line F-G .. 472

F. The Atlantic Region ........................ 472

G. The Complete Boundary Lines .............. 472

V. The Natural Prolongation Rule: A Fundamental RULE?...................................... 473

A. The North Sea Continental Shelf Cases.......... 473

B. The Anglo-French Continental Shelf Case........ 479

C. The Relevance of the Proceedings of

UNCLOS III............................ 482

D. Conclusion ........................... 483

VI. "Special Circumstances" and "Equitable PrinCIPLES" ....................................... 484

A. The North Sea Continental Shelf Cases ......... 484

B. The Meaning of "Special Circumstances" in Article 6 of the Geneva Convention ............... 486

1. Geographical Considerations .............. 487

2. Mineral Deposits ...................... 491

3. Navigation and Fishing Rights............ 492

4. Historical Special Circumstances ........... 494

5. Conclusion............................. 496

C. The Anglo-French Continental Shelf Case........ 496

1. Relationship Between Article 6 and International Customary Law ..................... 496

2. The Status of the Principle of Equidistance Under Article 6 and the Question of the Burden of Proof of Special Circumstances........ a. The Travaux Préparatoires of Article 6 ... 500

b. The Decision of the Court of Arbitration .. 505

3. No Legal Limit to Considerations Which May Be Taken into Account to Ensure the Application of Equitable Principles................ 507

4. The Proportionality Factor............... 508

5. Opposite-State and Adjacent-State Situations Distinguished .............................. 510

6. Islands and Archipelagos ................. 514

a. The Channel Islands ................... 514

b. The Scilly Isles ...................... 519

D. Conclusions ............................... 521

1. Relationship Between Article 6 and Rules of International Customary Law ............. 521

2. Status of Equidistance Rule and Burden of Proof of Special Circumstances ............ 521

3. No Legal Limit to Considerations Which May Be Taken into Account to Ensure the Application of Equitable Principles.............. 522 
4. Proportionality Factor.................. 522

5. Opposite-State and Adjacent-State Situations 522

6. Islands and Archipelagos as Special Circumstances................................. 522

VII. Macrogeographical Perspectives and the Court's COMPETENCE .................................. 522

VIII. The Status of THE UNCLOS III Negotiating TextS. 525

IX. The Significance of The Decision............. 528

\section{INTRODUCTION}

Since the Second World War, there have been a number of landmarks in the development of the rules of international law relating to the continental shelf. They include the Truman Proclamation (1945), 1 Lord Asquith's arbitral award in the Abu Dhabi case, 2 the draft articles and commentaries contained in the 1956 report of the International Law Commission, ${ }^{3}$ the Geneva Convention on the Continental Shelf (1958), 4 the judgment of the International Court of Justice (I.C.J.) in the North Sea Continental Shelf Cases (1969), 5 and the draft articles included in the successive versions of the negotiating text produced by the Third United Nations Conference on the Law of the Sea (UNCLOS III). 6 It seems more than likely that the decision of the Court of Arbitration in the Anglo-French Continental Shelf Case (1977-1978), ${ }^{7}$ will

1. Pres. Proc. No. 2667, 3 C.F.R. 67 (1943-1948 Compilation), reprinted in [1951] 1 UNITEd Nations Legislative Series, Laws aNd Regulations on the REgime of THE High SEAS 38. (1951).

2. Petroleum Dev. (Trucial Coast) Ltd. v. Sheikh of Abu Dhabi, 18 I.L.R. 144

3. Report of the International Law Commission to the General Assembly, 11 UN. GAOR, Supp. (No. 9) 1, U.N. Doc. A/3159 (1956), reprinted in [1956] 2 Y.B. INT'L L. Comm'N 253, U.N. Doc. A/CN.4/SER.A/1956/Add. 1 (1957).

4. [1964] 15 U.S.T. 471, T.I.A.S. No. 5578, 499 U.N.T.S. 311 [hereinafter cited as Geneva Convention].

5. [1969] I.C.J. 3.

6. Informal Composite Negotiating Text, UN. Docs. A/Conf. 62/WP. 10 \& Add. 1, reprinted in 8 UNCLOS III OR 1, and in 16 INT'L LEGAL MATERIALS 1099 (1977); Revised Single Negotiating Text, U.N. Doc. A/Conf. 62/WP. 8/Rev. 1, reprinted in 5 UNCLOS III OR 125 (1976); Informal Single Negotiating Text, U.N. Doc. A/Conf. 62/WP. 8, reprinted in 4 UNCLOS III OR 137, and in 14 INT'L LEGAL MATERIALs 689 (1975).

7. Delimitation of the Continental Shelf (Interpretation of the Decision of 30 June 1977), Decision of 14 March 1978 (United Kingdom v. France) (on file with the writer) [hereinafter cited as Decision of 14 March 1978]; Delimitation of the Continental Shelf, Decision of 30 June 1977 (United Kingdom v. France) (on file with the writer) [hereinafter cited as Decision]. As of February 2, 1979, official 
also come to be regarded as an important landmark in the development of these rules.

On the global level, the case is important as having provided the first opportunity for an international tribunal to interpret the rules on the delimitation of the continental shelf between neighbouring States in a dispute in which the States concerned were both parties to the Geneva Convention on the Continental Shelf. Inevitably, the judgment of the I.C.J. in the North Sea Cases was heavily relied upon in the pleadings and extensively commented upon by the Court of Arbitration. The case has thus provided a valuable opportunity for a re-examination of the earlier judgment, given some eight years previously on the basis of international customary law. It will be argued later that the Court of Arbitration's decision is in some respects better founded than the judgment of the I.C.J. and that its publication may help to moderate the influence of the North Sea judgment and to discourage the more extravagant interpretations that have been put upon some of the dicta in that judgment. At a time when UNCLOS III is still struggling to reach agreement on, inter alia, the rules for the delimitation of the continental shelf and of the exclusive economic zone, it may be hoped that the weary draftsmen will derive new insights from the Court of Arbitration's timely clarification of the law.

It seems likely that the court's decision will also be of considerable significance in the more local context. The United Kingdom has still to settle its continental shelf boundary with Ireland ${ }^{8}$ in the area adjacent to that which was the subject of the court's decision, as well as in the Rockall sector further north.9 As will be seen, many of the court's dicta may well be considered to have an important bearing upon the problems dividing the parties in these other areas.

The remainder of this article falls into eight main parts. Part II describes "the arbitration area" and presents the problem as it was put to the Court of Arbitration by the parties. Part III is concerned with the question of the applicable law. Part IV contains a brief general description of the boundary lines laid down by the court, and parts V-VIII present a commentary on selected aspects

publication of the court's decisions is awaited. The writer is indebted to Sir Ian Sinclair, Legal Adviser to the Foreign and Commonwealth Office, for making a copy of the decisions available to him.

8. Ireland and the United Kingdom have agreed to refer the question to "some form of third party settlement of a judicial nature." Decision, supra note 7, para. 26.

9. On the Rockall sector, see Brown, Rockall and the Limits of National Jurisdiction of the United Kingdom (pts. 1-2), 2 MARINE POL'Y 181, 275 (1978). 
of the court's decision. Finally, part IX attempts an evaluation of the significance of the decision.

\section{The Dispute}

Following correspondence and informal contacts in 1964 and 1965, the United Kingdom and France opened negotiations for the delimitation of their respective continental shelves in 1970. The negotiations, which continued until the beginning of 1974, were unsuccessful, and the two governments subsequently agreed to submit their dispute to an arbitral tribunal.10

As is made clear in the Preamble of the Arbitration Agreement, signed in Paris on July 10, 1975,11 agreement in principle had already been reached on the delimitation of the continental shelf in the English Channel eastward of thirty minutes west of the Greenwich Meridian. The question put to the Court of Arbitration in Article 2(1) of the agreement was as follows: "What is the course of the boundary (or boundaries) between the portion of the continental shelf appertaining to the United Kingdom and the Channel Islands and to the French Republic, respectively, westward of thirty minutes west of the Greenwich Meridian as far as the 1,000-metre isobath?"12 Under Article 9(1), the court's decision was to include "the drawing of the course of the boundary (or boundaries) on a chart."13

It was noted, ex abundanti cautela, that the choice of the 1,000 metre isobath was without prejudice to the position of either government concerning the outer limit of the continental shelf. ${ }^{14}$ The arbitration area is shown on Figure 1.15

The Court of Arbitration consisted of five members: Professors

10. Decision, supra note 7 , at 4 .

11. Arbitration Agreement of July 10, 1975, United Kingdom-France, [1975] Gr. Brit. T.S. No. 137 (Cmnd. 6280).

12. Id. art. 2(1).

13. Id. art. $9(1)$.

14. Id. art. 2(2).

15. See p. 466 infra. The line $X-Y$ is the "rectified" version of this line specified in the court's interpretative Decision of 14 March 1978, note 7 supra. The writer is indebted to Dr. H.D. Smith for drawing the map. 


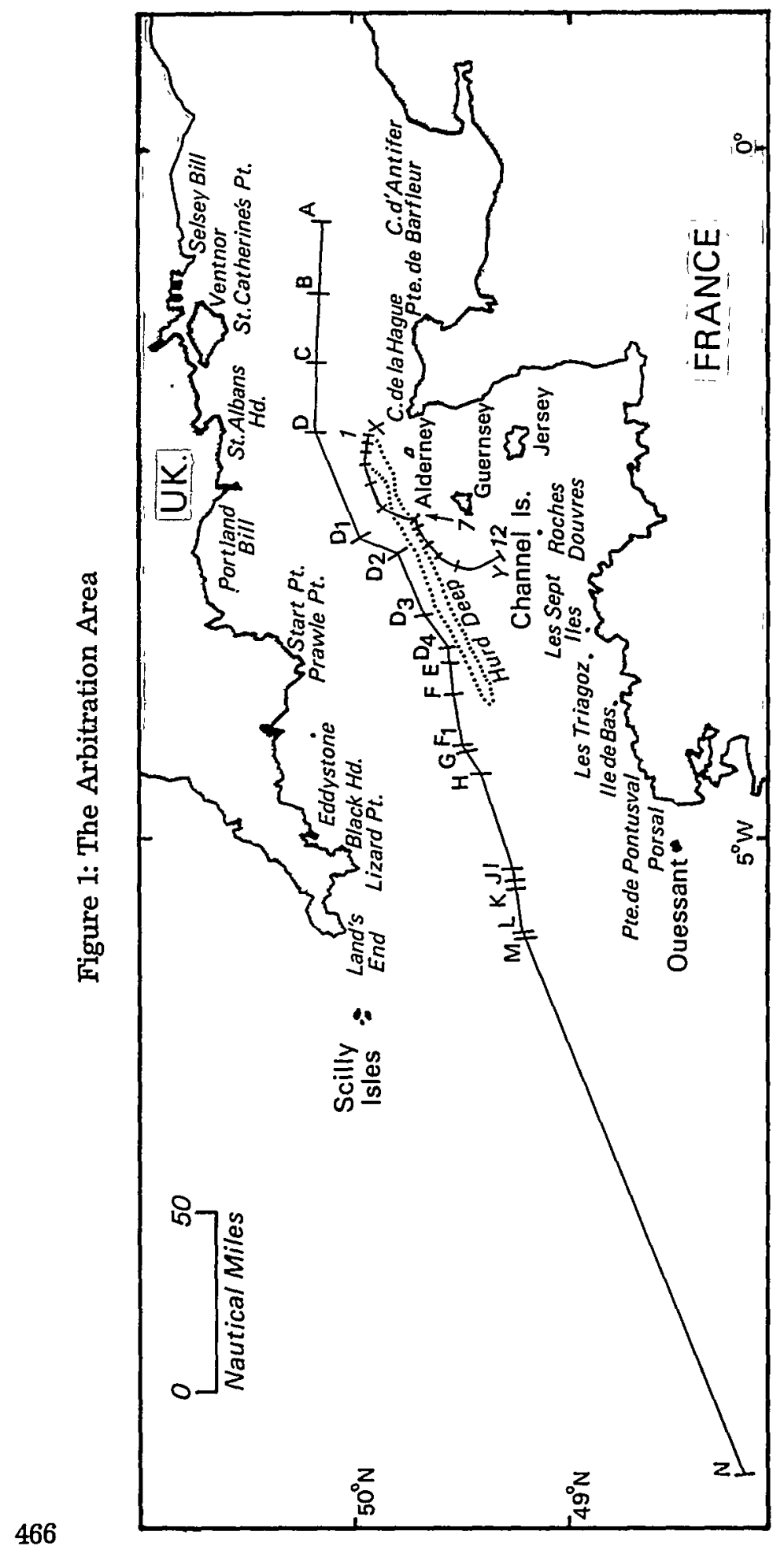


Briggs, Castren (President), Reuter (subsequently replaced by $M$. Gros), Ustor, and Waldock. The court appointed as expert Mr. Hans Emmel, former Director of Nautical Surveys and Charting, Deutsches Hydrographisches Institut, Hamburg.

Under Article 10 of the Arbitration Agreement, the two governments agreed to accept as final and binding upon them the decision of the court "on the question specified in Article 2 of the present Agreement,"16 but either party was to be entitled, within three months of the rendering of the decision, to refer to the court any dispute as to the meaning and scope of the decision. ${ }^{17}$ The United Kingdom government took the view that there was a discrepancy between the court's findings in the body of its decision and the precise boundary lines specified in the dispositif and drawn by the court's expert on the Boundary-Line Chart. The government accordingly sought from the court a definitive declaration on the meaning and scope of the original decision in relation to two parts of the boundary line. As will be seen, the court, in its interpretative decision of March 14, 1978, acknowledged the need for a rectification of the dispositif and Chart in relation to the boundary line in the Channel Islands sector but rejected the United Kingdom's contentions in relation to the boundary line in the Atlantic sector. 18

\section{The Applicable LaW}

Under Article 2(1) of the Arbitration Agreement, the court was asked to decide the question put to it "in accordance with the rules of international law applicable in the matter as between the Parties."19

Both States were parties to the Geneva Convention on the Continental Shelf,20 but France contended that the Convention had never entered into force between France and the United Kingdom because of the latter's refusal to accept certain reservations made by France when acceding to the Convention.21 Limitations of

16. Id. art. 10.

17. Id.

18. Decision of 14 March 1978, note 7 supra. See also notes $43 \& 275$ infra.

19. Arbitration Agreement of July 10, 1975, United Kingdom-France, [1975] Gr. Brit. T.S. No. 137 (Cmnd. 6280).

20. Note 4 supra.

21. Decision, supra note 7, at 11, 19. For the text of French reservations and United Kingdom response to them, see id. paras. 33-34. 
space forbid more than a passing reference to the many interesting observations of the court in its analysis of the effect of the French reservations and of the United Kingdom's refusal to accept them. It must suffice to note the court's conclusions. Rejecting the arguments of the United Kingdom, the court found that all three of France's reservations were true reservations (rather than interpretative declarations) and were admissible. On examining the effect of those reservations in the circumstances of this case, however, the court came to the conclusion that neither of the first two reservations would in fact affect the application to the case of Article 6 of the Geneva Convention.22

The court did, however, attach more significance to the third French reservation. It designated, inter alia, the "Bay of Granville" as being an area in which France considered that "special circumstances" exist within the meaning of Article 6 of the Geneva Convention.23 The court found that the expression "the Bay of Granville" had to be viewed as relating to the Channel Islands region as a whole. The United Kingdom having rejected the reservation, the court held that Article 6 was excluded and that the delimitation in the Channel Islands region must therefore be determined by reference to the rules of international customary law.24

The court was thus able to conclude that, except in the Channel Islands region, Article 6 was applicable in principle to the delimitation of the continental shelf in the arbitration area.25

\section{A. The Relationship of Article 6 to International Customary Law.}

As has been seen, the court rejected the French contention that the Geneva Convention was not the applicable law. The French argument was two-fold: The Convention did not apply (1) because the Convention had never entered into force between France and the United Kingdom and (2) because it had been rendered obsolete by recent developments in customary law. ${ }^{26}$ This latter argument gave the court the opportunity to state its opinion on the relationship between the Geneva Convention and recent developments in the United Nations and in State practice.

The French argument is summed up in the following passages

22. Id. paras. $71-73$.

23. Id. para. 74 .

24. Id.

25. Id. para. 75.

26. Id. at 11-12, 19-20. 
from the French government's submissions in the oral proceedings. France argued

[t] hat the recent development of customary law, which was stimulated particularly by the work of the United Nations, the reactions on the part of the Governments to this work, the discussions and negotiations at the Third Conference on the Law of the Sea, and the endorsement of this development in the practice of States with respect to economic zones and fishing zones of 200 miles, have rendered the 1958 Conventions obsolete. ${ }^{27}$

It followed, in the French government's view,

[t] hat the rules of international law applicable in this matter between the Parties are the rules of customary law, as stated in particular by the International Court of Justice in the North Sea Continental Shelf cases and confirmed by the subsequent practice of States and the work of the Third Conference on the Law of the Sea. 28

The court was prepared to recognise

both the importance of the evolution of the law of the sea which is now in progress and the possibility that a development in customary law may, under certain conditions, evidence the assent of the States concerned to the modification, or even termination of previously existing treaty rights and obligations. ${ }^{29}$

Having examined the evidence, however, the court came to the conclusion that

neither the records of the Third United Nations Conference on the Law of the Sea nor the practice of States outside the Conference provide any such conclusive indication that the Continental Shelf Convention of 1958 is today considered by its parties to be already obsolete and no longer applicable as a treaty in force. ${ }^{30}$

The court went on to emphasise, however, that this did not mean

that it regards itself as debarred from taking any account in these proceedings of recent developments in customary law. On the contrary, the Court has no doubt that it should take due account of the evolution of the law of the sea in so far as this may be relevant in the context of the present case. ${ }^{31}$

Clearly, the extent to which the court would take account of recent developments would depend upon the degree to which the alleged rules had emerged from their formative stage of development and had come to be accepted as new norms of international customary law. This court, like the I.C.J., could not "as a court of law ... render judgment sub specie legis ferendae, or anticipate the law before the legislator has laid it down."32 When, however,

27. Id. at 20.

28. Id.

29. Id. para, 47.

30. Id.

31. Id. para. 48 .

32. Fisheries Jurisdiction Case (United Kingdom v. Iceland), [1974] I.C.J. 3, para. 53. 
the rules of international customary law could be clearly established, the court made it clear that having found Article 6 of the Convention applicable in principle 33 did not mean that it considered the rules of customary law discussed in the North Sea Continental Shelf Cases to be inapplicable:

As already pointed out, the provisions of Article 6 do not define the conditions for the application of the equidistance-special circumstances rule; moreover, the equidistance-special circumstances rule and the rules of customary law have the same object-the delimitation of the boundary in accordance with equitable principles. In the view of this Court, therefore, the rules of customary law are a relevant and even essential means both for interpreting and completing the provisions of Article 6.34

\section{The Boundary Lines}

To simplify the task of determining the boundary lines, the court divided the arbitration area into sectors. It may facilitate understanding of the commentary on various aspects of the court's decision, contained in parts V-VIII, if it is prefaced with a brief general description of these sectors and of the boundary lines laid down by the court.

\section{A. The Area of Narrow Waters Between the Channel Islands Archipelago and the Coasts of Normandy and Brittany}

Because of the precise formulation of Article 2(1) of the Arbitration Agreement, 35 the geographical circumstances, and the replies of the parties to questions put to them by the court, the court held that it was without competence to delimit the boundary in the disputed area. ${ }^{36}$ It added the observation that:

In narrow waters such as these, strewn with islets and rocks, coastal

States have a certain liberty in their choice of base-points; and the selection of base-points for arriving at a median line in such waters which is at once practical and equitable appears to be a matter peculiarly suitable for determination by direct negotiations between the Parties. 37

\section{B. The Area Ultimately Delimited by the Line $A-D^{38}$}

The court had no difficulty in determining that this most easterly segment of the boundary line should be based on a median line. Such a line was indicated by the applicable law in a case such as this where opposite States abutted upon an area

33. Decision, supra note 7 , para. 75 .

34. Id.

35. Arbitration Agreement of July 10, 1975, United Kingdom-France, art. 2(1),

[1975] Gr. Brit. T.S. No. 137 (Cmnd. 6280).

36. Decision, supra note 7 , paras. 19-22.

37. Id. para. 22.

38. See Figure 1 at p. 466 supra. 
characterised by the essential continuity of the continental shelf and by the absence of special circumstances. ${ }^{39}$

\section{The Areas Ultimately Delimited by the Lines $E-F$ and $G-J$}

The areas between and south of points $D$ and $E$ called for separate consideration in view of the presence of the Channel Islands, as did the area between points $F$ and $G$ because of a difference of view over the legal status of Eddystone Rock and its effect on the boundary line. Leaving these two segments for later consideration, the court again had no difficulty in finding that the lines E-F and G-J should be drawn on the basis of the median line as agreed by the parties. 40 The court noted that point $J$, the point equidistant from Basse Vincent (north coast of Finistere) and the Stags (off the Lizard in Cornwall), marked the westerly terminal of the "simplified" median line that had been agreed between the parties. It followed that "the agreement between the Parties regarding the median line in the western segment of the Channel did not extend to the use of Ushant or the Scilly Isles as basepoints for delimiting a median line boundary." 41

\section{The Channel Islands Sector}

The court decided that the presence of the Channel Islands close to the French coast was "a circumstance creative of inequity" and a "special circumstance" within the meaning of Article 6 of the Geneva Convention.42 It went on to find that the situation demanded a two-fold solution. First, a line should be drawn through points $\mathrm{D} 1, \mathrm{D} 2, \mathrm{D} 3$, and $\mathrm{D} 4$-that is, a median line constructed without reference to the Channel Islands. Second, a separate boundary line, marked $X-Y$ on the Boundary Chart, had to be drawn at a distance of twelve miles from the territorial sea baselines of the Channel Islands. Such a line would not allow the French continental shelf to encroach upon the established twelvemile fishery zone of the Channel Islands. 43

39. Decision, supra note 7 , paras. 108-10.

40. Id. para. 120.

41. Id. para. 118.

42. Id. para. 196. As was seen above, the court had earlier held that the rules of international customary law applied in this area, but the court tested its conclusion, amived at on the basis of international customary law, by applying also the equidistance-special circumstances rule of Article 6 of the Convention.

43. Id. paras. 201-02. As noted above, see text accompanying note 18 supra, 


\section{E. The Area Ultimately Delimited by the Line F-G}

In this area, the court found that Eddystone Rock should be treated as a relevant basepoint for the construction of a median line. 44

\section{F. The Atlantic Region}

The court, being of the opinion that the opposite-States situation of the parties continued for a short distance west of point $\mathrm{J}$, prescribed that the median line should be extended westward through point $\mathrm{K}$ to point $\mathrm{L} .45$ West of point $\mathrm{L}$, however, it was necessary to have regard for the fact that the parties abutted upon the continental shelf in a side-by-side situation rather than in an opposite-States situation. As the court explained, following the thinking of the I.C.J., in such a lateral situation the distorting effect on an equidistance line of any special geographical feature is the more marked the further the line extends seawards. ${ }^{46}$ In this context the court found that the prolongation of the Scilly Isles some distance further westwards than the island of Ushant, superadded to the greater projection of the Cornish mainland westwards beyond Finistere, constituted a "special circumstance" justifying a departure from an equidistance line. 47 The court remedied the potential inequity by applying the "half-effect" method. Thus, in delimiting the equidistance line L-N, only half, instead of full, effect is given to the Scilly Isles. The line is constructed by first drawing two equidistance lines, one using the offshore island as a basepoint and the other ignoring the island. A boundary giving half effect to the island is then the line drawn mid-way between those two equidistance lines. 48

\section{G. The Complete Boundary Lines}

The complete boundary lines thus consist of (1) an equidistance line from point $\mathrm{A}$ to point $\mathrm{N}$, modified by the half-effect method in the segment west of point $M$, and (2) a twelve-mile line to the north and west of the Channel Islands. The line A-N resulted from application of Article 6 of the Geneva Convention and

the court, in its Decision of 14 March 1978, supra note 7, para. 37, acknowledged the need for a rectification of the coordinates specified for the line $X-Y$ in the original Decision, note 7 supra, of June 30,1977 . It is the rectified line that is shown in Figure 1 at p. 466 supra.

44. Decision, supra note 7, para. 144 .

45. Id. para. 252.

46. Id. para. 96 (citing North Sea Continental Shelf Cases, [1969] I.C.J. 3, para $89(a))$. See also id. para. 239.

47. Id. para. 244 .

48. Id. para. 251. 
the twelve-mile line from application of the rules of international customary law.

It is hoped that this bird's-eye view of the court's findings will have supplied a background against which the following commentary on various selected aspects of the court's decision may be readily understood.

\section{The Natural Prolongation Rule: A Fundamental Rule?}

The origin of the notion that the concept of "natural prolongation" is relevant for the delimitation of the lateral boundaries of the continental shelf is to be found in the judgment of the I.C.J. in the North Sea Continental Shelf Cases.49 That judgment was of course given on the basis of international customary law, but the dicta in question have been widely considered relevant to the interpretation of Article 6 of the Geneva Convention and have clearly influenced the draftsmen of the UNCLOS III negotiating texts.50 The decision of the Court of Arbitration provides a timely opportunity for a review of this proposition. Following a critical résumé of the I.C.J.'s judgment, an analysis will be presented of the relevant passages in the decision of the Court of Arbitration. Finally, attention will be drawn to pertinent draft articles in the Informal Composite Negotiating Text. 51

\section{A. The North Sea Continental Shelf Cases}

In its analysis of the rules of international customary law in this case, the I.C.J. attributed a special status to the Truman Proclamation. The Proclamation, having come to be regarded as the starting point of the positive law on the continental shelf, 52 "must be considered as having propounded the rules of law in this field."53

It had been argued in the Truman Proclamation that "the conti-

49. [1969] I.C.J. 3.

50. Informal Composite Negotiating Text, U.N. Docs. A/Conf. 62/WP. 10 \& Add. 1, reprinted in 8 UNCLOS III OR 1, and in 16 INT'L LEGAL MATERLALS 1099 (1977); Revised Single Negotiating Text, U.N. Doc. A/Conf. 62/WP. 8/Rev. 1, reprinted in 5 UNCLOS III OR 125 (1976); Informal Single Negotiating Text, U.N. Doc. A/Conf. 62/WP. 8, reprinted in 4 UNCLOS III OR 137, and in 14 INT'L. LEGAL MATERIALS 689 (1975).

51. U.N. Docs. A/Conf. 62/WP. 10 \& Add. 1, reprinted in 8 UNCLOS III OR 1, and in INT'L Legal MATERIALS 1099 (1977).

52. [1969] I.C.J. para. 47.

53. Id. para. 86 . 
nental shelf may be regarded as an extension of the land-mass of the coastal nation and thus naturally appurtenant to it."54 The court described as the "chief doctrine" enunciated by the proclamation the proposition that the coastal State has "an original, natural, and exclusive (in short a vested) right to the continental shelf off its shores." 55

In other passages the court referred to this same notion at greater length:

What confers the ipso jure title which international law attributes to the coastal State in respect of its continental shelf, is the fact that the submarine areas concerned may be deemed to be actually part of the territory over which the coastal State already has dominion,-in the sense that, although covered with water, they are a prolongation or continuation of that territory, an extension of it under the sea. From this it would follow that whenever a given submarine area does not constitute a natural-or the most natural-extension of the land territory of a coastal State, even though that area may be closer to it than it is to the territory of any other State, it cannot be regarded as appertaining to that State; - or at least it cannot be so regarded in the face of a competing claim by a State of whose land territory the submarine area concerned is to be regarded as a natural extension, even it it is less close to it. ${ }^{56}$

Again, the court described as "the most fundamental of all the rules relating to the continental shelf" the rule that:

[T] he rights of the coastal State in respect of the area of continental shelf that constitutes a natural prolongation of its land territory into and under the sea exist ipso facto and $a b$ initio, by virtue of its sovereignty over the land, and as an extension of it in an exercise of sovereign rights for the purpose of exploring the seabed and exploiting its natural resources. 57

The court drew from this fundamental rule the conclusion that, in accordance with "the basic concept of continental shelf entitlement," 58 the process of delimitation was essentially one of drawing a boundary line between areas that already appertained to one or other of the States affected. The delimitation had to "be equitably effected, but it [could not] have as its object the awarding of an equitable share, or indeed of a share, as such, at all-for the fundamental concept involved [did] not admit of there being anything undivided to share out."59 It may be noted in passing that it is quite possible to accept the proposition that the object of delimitation is not the award of equitable shares without accepting the relevance of the concept of natural prolongation to the question of lateral delimitation.

54. Pres. Proc. No. 2667, 3 C.F.R. 67 (1943-1948 Compilation), reprinted in [1951] 1 UNITED Nations Legislative Series, LawS aND REgULATIONS ON THE REGIME OF ThE HIGH SeAs 38.

55. [1969] I.C.J. para. 47.

56. Id. para. 43.

57. Id. para. 19.

58. Id. para. 20.

59. Id. 
Another basic concept that the court drew from the Truman Proclamation was that delimitation must be effected in accordance with equitable principles. 60 Subsequently, the court stated that equitable principles must be applied "in accordance with the ideas which have always underlain the development of the legal régime of the continental shelf in this field," including the idea that "the continental shelf of any State must be the natural prolongation of its land territory and must not encroach upon what is the natural prolongation of the territory of another State."61

In another passage, 62 the court explained that there is no legal limit to the considerations that States may take into account to ensure the application of equitable principles. Various features had to be put into the balance. Two of these features, as described by the court, have a bearing on the concept of natural prolongation. Thus, of the geological factor, the court said:

[I]t can be useful to consider the geology of [the] shelf in order to find out whether the direction taken by certain configurational features should influence delimitation because, in certain localities, they point-up the whole notion of the appurtenance of the continental shelf to the State whose territory it does in fact prolong. 63

Of the geographical factor, it said:

[I]t is . . . necessary to examine closely the geographical configuration of the coastlines of the countries whose continental shelves are to be delimited. This is one of the reasons why the Court does not consider that markedly pronounced configurations can be ignored; for, since the land is the legal source of the power which a State may exercise over territorial extensions to seaward, it must first be clearly established what features do in fact constitute such extensions. 64

Finally, attention may be drawn to the court's reference to overlapping natural prolongations. The court foresaw that application of equitable principles in accordance with the factors it had identified might lead to an overlapping of the areas appertaining to the States concerned. It accordingly provided that such a situation must be dealt with by an agreed division or, failing that, an equal division of the overlapping areas; alternatively, there might be agreement for joint exploitation, this being particularly appropriate when it was a question of preserving the unity of a deposit.65

60. See E. Brown, The Legal Regme of Hydrospace $43-47$ (1971).

61. [1969] I.C.J. para. 85 .

62. Id. para. 93 .

63. Id. para. 95.

64. Id. para. 96.

65. Id. para. 99. 
In a work published in 1971, the writer suggested that the court's judgment was open to criticism, inter alia, because of its attitude to the Truman Proclamation.66 It was argued that the court had elevated vague passages in the proclamation to the status of fundamental principles and then proceeded to deduce detailed rules from them by a method that could not be considered to be a legitimate use of the deductive process. It was suggested that the court's use of the description of the continental shelf in the Truman Proclamation as being "an extension of the land mass and thus naturally appurtenant to it" 67 stretched the language of the proclamation beyond all reason. It was concluded that:

There is really nothing in the Proclamation or in subsequent United States practice [68] to suggest that the concept of natural appurtenance had any bearing on the question of lateral delimitation. The concept of natural prolongation belongs to the problem of the seaward extension of the continental shelf, not to its delimitation as between opposite or adjacent States. This is clearly indicated by the admission that areas of natural appurtenance may overlap-an admission which obliged the Court to resort, somewhat "unnaturally," to distinguishing between "natural" and "most natural" prolongations of territory. [69] It may be reasonable to speak of the continental shelf (perhaps more accurately, the continental terrace or margin) [70] as being the natural prolongation of the land territory as a whole (on the basis of a distinction between the geological character of the continental "land" mass and that of the bed and subsoil of the true ocean); it is quite another matter to say that a particular area of shelf is the natural prolongation of the territory of State $A$, that is, of a politically determined area. It is surely the case that any part of the continental shelf is a natural prolongation of the territory of any State which lies on the same continental land-mass. There is nothing natural about carving up the shelf to allow for unity of selected geological features and even less for unity of deposits. 71

In short, it was the writer's opinion in 1971 that the concept of natural prolongation was irrelevant to the delimitation of lateral boundaries of the continental shelf under international customary law.

Because the court described the natural prolongation rule as "the most fundamental of all the rules relating to the continental shelf, enshrined in Article 2 of the 1958 Geneva Convention, though quite independent of it,"72 there is every reason to think that the court would have regarded the concept of natural prolongation as relevant also to the delimitation of a lateral boundary

66. E. Brown, supra note 60 , at $47-51$.

67. Id. at 49 .

68. See id. at $48 \mathrm{nn} .40$ \& 41 .

69. See text accompanying note 56 supra.

70. The continental terrace includes the geological continental shelf and continental slope. The continental margin includes the terrace and the continental rise. E. Brown, supra note 60 , at 74 .

71. Id. at 49 .

72. [1969] I.C.J. para. 19. 
under Article 6(2) of the Convention. However, because Article 6(2) contains specific rules for the delimitation of lateral boundaries and nowhere mentions any such concept as natural prolongation, this view hardly seems tenable. ${ }^{73}$

The view was expressed above that the concept of natural prolongation belongs to the problem of the seaward extension of the continental shelf, not to its delimitation as between opposite or adjacent States. It is perhaps necessary to qualify this view by saying that it holds good only so long as it may be assumed that the neighbouring States abut upon one continuous continental shelf. Thus, if there is "a major and persistent structural discontinuity of the seabed and subsoil of such a kind as to interrupt the essential geological continuity of the continental shelf,"74 then in a sense the concept of natural prolongation would be relevant to the question of delimitation. It would, however, be more accurate in such cases to describe the situation in terms of two separate continental shelves. This is the case, for example, with the Timor Trench boundary between Australia and Indonesia, the 2,000-metre-deep trench marking the northern limit of the Australian continental margin.

The Timor Trench situation is of course one between opposite States. While theoretically possible, it would be extremely unusual to find such a major geological discontinuity extending laterally across the shelf in the vicinity of the land boundary of adjacent States. It is quite normal to find relatively superficial or secondary depressions or channels running across a continuous continental margin-often originating in an ancient fluvio-glacial drainage system-but such features are not major geological discontinuities.

The Court of Arbitration had occasion to deal with such a secondary feature in the Anglo-French Case when considering the United Kingdom's alternative submission that the continental shelf boundary should follow the Hurd Deep-Hurd Deep Fault Zone, should the court decide that those geological faults were such as to "interrupt the essential geological continuity of the continental shelf." 75

The Hurd Deep is situated near the centre of the English Chan-

73. Geneva Convention, note 4 supra.

74. Decision, supra note 7, para. 104.

75. Id. para. 106. 
nel just off the Channel Islands. 76 It is some 150 kilometres long, two to six kilometres wide, and has an average depth of about 115 metres-only forty-five metres below the average level of the floor of the Channel. It appears to be part of a series of faults extending for a distance of some eighty nautical miles, with a width of between one and three nautical miles and a depth of over 100 metres.77

The parties were at one in considering that the faults did not detract from the geological continuity of the continental shelf, though the United Kingdom, in its alternative submission, did consider that the Hurd Deep Fault Zone constituted a major and persistent rift in the structure of the shelf. ${ }^{78}$

The Court of Arbitration did not agree:

Whichever way the matter is put, the Court does not consider that the Hurd Deep-Hurd Deep Fault Zone is a geographical feature capable of exercising a material influence on the determination of the boundary either in the Atlantic region or in the English Channel. The Court shares the view repeatedly expressed by both Parties that the continental shelf throughout the arbitration area is characterised by its essential geological continuity. The geological faults which constitute the Hurd Deep and the so-called Hurd Deep Fault Zone, even if they be considered as distinct features in the geomorphology of the shelf, are still discontinuities in the seabed and subsoil which do not disrupt the essential unity of the continental shelf either in the Channel or the Atlantic region. Indeed, in comparison with the deep Norwegian Trough in the North Sea, they can only be regarded as minor faults in the geological structure of the shelf; and yet the United Kingdom agreed that the trough should not constitute an obstacle to the extension of Norway's continental shelf boundary beyond that major fault zone. Moreover, to attach critical significance to a physical feature like the Hurd Deep-Hurd Deep Fault Zone in delimiting the continental shelf boundary in the present case would run counter to the whole tendency of State practice on the continental shelf in recent years. 79

The court went on in a later passage ${ }^{80}$ to say that even if it were to find that the equidistance line was not the appropriate boundary, it would be because some geographical feature amounted to a "special circumstance" justifying another boundary under Article 6 or because, by rendering the equidistance line inequitable it called for the use of some other method under international cus. tomary law. The court proceeded then to say that:

[T] he axis of the Hurd Deep-Hurd Deep Fault Zone is placed where it is simply as a fact of nature, and there is no intrinsic reason why a boundary along that axis should be the boundary which is justified by the special circumstances under Article 6 or which, under customary law, is needed to remedy the particular inequity.81

\footnotetext{
76. See Figure 1 at p. 466 supra.

77. Decision, supra note 7, para. 9.

78. Id. para. 12.

79. Id. para. 107.

80. Id. para. 108.

81. Id.
} 
It is of course true that the Hurd Deep is a very minor depression in the shelf. Nevertheless, the references that the court made to (1) the Norwegian Trough, (2) the absence of any disruption of the essential unity of the continental shelf, and (3) "the whole tendency of State practice . . . in recent years"82 strongly suggest that its reasoning would also apply to other channels or depressions that could not be regarded as major geological discontinuities.

\section{B. The Anglo-French Continental Shelf Case}

This case was primarily concerned with a situation of opposite States (indeed, exclusively so in the Channel Islands sector, in relation to which most of the court's many references to natural prolongation were made). As noted above, however, the same considerations apply to both opposite- and adjacent-coast situations so long as the States in question abut upon one continuous continental shelf. The decision is therefore relevant also to the case of a lateral delimitation between adjacent States.

In paragraph 77 of its decision, the Court of Arbitration quoted, apparently with approval, the passage in the judgment in the North Sea Continental Shelf Cases in which the I.C.J. described the principle that a coastal State has inherent rights in the continental shelf that constitutes the natural prolongation of its land territory as "the most fundamental of all the rules relating to the continental shelf." 33 It went on to refer to two conclusions that the I.C.J. had drawn from this fundamental rule and that the Court of Arbitration described as "being of general application."84

The second of these conclusions was "that the continental shelf of any State must be the natural prolongation of its land territory and must not encroach upon what is the natural prolongation of the territory of another State."8s The Court of Arbitration went on to say that: "This conclusion follows directly from the fundamental rule itself and is, indeed, merely an application of that rule to the context of a single area of continental shelf upon which the territories of two or more States abut."86

82. Id. para. 107.

83. Id. para. 77 (quoting [1969] I.C.J. para. 19).

84. Id.

85. Id. para. 79 .

86. Id. 
So far, then, the Court of Arbitration seems to be at one with the I.C.J. In the immediately following sentence, however, there is a strong hint that the Court of Arbitration takes a very different view from that of the I.C.J. on the relevance of the concept of natural prolongation to lateral delimitation; and this hint, as will be seen, becomes a certainty in later passages of the decision. The Court of Arbitration went on from the above passage to say that:

So far as delimitation is concerned, however, this conclusion states the problem rather than solves it. The problem of delimitation arises precisely because in situations where the territories of two or more States abut on a single continuous area of continental shelf, it may be said geographically to constitute a natural prolongation of the territory of each of the States concerned. Consequently, it is rather in the rules of customary law discussed in the North Sea Continental Shelf cases and which are specifically directed to delimitation that guidance may be sought regarding the principles to be applied in determining the boundary of the continental shelf in such situations. ${ }^{87}$

This would seem to be tantamount to saying that the concept of natural prolongation is really irrelevant to the problem of lateral delimitation.

At first sight, this conclusion hardly seems to square with paragraph 191 of the decision of the Court of Arbitration:

The continental shelf of the Channel Islands and of the mainlands of France and of the United Kingdom, in law, appertains to each of them as being the natural prolongation of its land territory under the sea. The physical continuity of the continental shelf of the English Channel means that geographically it may be said to be a natural prolongation of each one of the territories which abut upon it. The question for the Court to decide, however, is what areas of continental shelf are to be considered as legally [emphasis original] the natural prolongation of the Channel Islands rather than of the mainland of France. In international law, as the United Kingdom emphasized in the pleadings, the concept of the continental shelf is a juridical concept which connotes the natural prolongation under the sea not of a continent or geographical land mass but of the land territory of each State. And the very fact that in international law the conti. nental shelf is a juridical concept means that its scope and the conditions for its application are not determined exclusively by the physical facts of geography but also by legal rules. Moreover, it is clear both from the insertion of the "special circumstances" provision in Article 6 and from the emphasis on "equitable principles" in customary law that the force of the cardinal principle of "natural prolongation of territory" is not absolute, but may be subject to qualification in particular situations. ${ }^{88}$

Prima facie, this passage might seem to endorse the I.C.J.'s conception of the legal continental shelf as being the natural prolongation not of a natural feature but of a political feature-that is, the land territory of a State, the area of which is, clearly, a product of history and politics. It would perhaps be more accurate, however, to say that the Court of Arbitration pays lip service to this conception in the earlier part of this quotation but then pro-

87. Id.

88. Id. para. 191 (emphasis added). 
ceeds, in the later italicised part, to hint once more that the concept of natural prolongation may not be relevant to the problem of lateral delimitation. Admittedly, in this passage it is still no more than a hint, and the Court of Arbitration still seems determined not to diverge too far from the line taken by the I.C.J. The same can perhaps be said of paragraph 194:

\begin{abstract}
The true position, in the opinion of the Court, is that the principle of natural prolongation of territory is neither to be set aside nor treated as absolute in a case where islands belonging to one State are situated on continental shelf which would otherwise constitute a natural prolongation of the territory of another State. The application of that principle in such a case, as in other cases concerning the delimitation of the continental shelf, has to be appreciated in the light of all the relevant geographical and other circumstances. When the question is whether areas of continental shelf, which geologically may be considered a natural prolongation of the territories of two States, appertain to one State rather than to the other, the legal rules constituting the juridical concept of the continental shelf take over and determine the question. Consequently, in these cases the effect to be given to the principle of natural prolongation of the coastal State's land territory is always dependent not only on the particular geographical and other circumstances but also on any relevant considerations of law and equity. 89
\end{abstract}

If, however, one penetrates the theoretical smokescreen and determines the actual ratio decidendi in relation to the delimitation in the Channel Islands region, the real position of the Court of Arbitration becomes apparent. The real grounds of the court's decision can be perceived by a close examination of the following passages, the first of which follows immediately after paragraph 191, reproduced above, and reads as follows: "Accordingly, in the opinion of the Court, the principle of natural prolongation of territory cannot be said to require that the continental shelf to the north and north-west of the Channel Islands should be considered as automatically and necessarily appurtenant to them rather than to the French Republic."9o

Having thus eased the concept of natural prolongation out of its way, the court proceeds, in paragraph 195, to reformulate the question it has to answer:

[T] he question is whether the Channel Islands should be given the full benefit of the application of the principle of natural prolongation in the areas to their north and north-west or whether their situation close to the mainland of France requires, on equitable grounds, some modification of the application of the principle in those areas. ${ }^{91}$

89. Id. para. 194.

90. Id. para. 192.

91. Id. para. 195. 
The Court of Arbitration had no difficulty in finding the "ground of equity" "in the particular circumstances of the present case and in the particular equality of the two States in their geographical relation to the continental shelf of the Channel."92 It decided that the presence of the Channel Islands close to the French coast must be considered, prima facie, as a circumstance creative of inequity and a "special circumstance" within the meaning of Article 6 of the Geneva Convention. This prima facie finding was then tested against the "relevant circumstances" or "equitable considerations" invoked by the United Kingdom, namely: (1) the political and economic importance of the Channel Islands, (2) their close ties with the United Kingdom and the latter's security and defence responsibility for them, and (3) the fact that the Islands have no possibility of an appreciable area of continental shelf except to their west and north. The court, weighing these equitable considerations in the balance, decided that the continental shelf of the Channel Islands should be restricted to a twelve-mile enclave which, on the assumption that the United Kingdom later extends its territorial sea to twelve miles, will in effect mean that the Channel Islands will have no continental shelf at all!93

It is revealing at this point to pose the question: What difference would it have made to the court's decision if it had made no mention of the concept of natural prolongation? The answer is clear: It would have made no difference whatsoever. This answer is not surprising, for the ratio of the decision is in reality nothing more nor less than the substance of the special-circumstances rule of Article 6 of the Geneva Convention. ${ }^{94}$ This being so, this arbitral award can hardly be considered to have confirmed the view that the concept of natural prolongation is relevant for the delimitation of the continental shelf between opposite or adjacent States.

\section{The Relevance of the Proceedings of UNCLOS III}

In its pleadings in the Anglo-French Case, France argued

[t] hat the recent development of customary law, which was stimulated particularly by the work of the United Nations, the reactions on the part of Governments to this work, the discussions and negotiations at the Third Conference on the Law of the Sea, and the endorsement of this development in the practice of States with respect to economic zones and fishing zones of 200 miles, have rendered the 1958 Conventions obsolete. 95

The Court of Arbitration was definite in holding that the Geneva
92. Id.
93. Id. paras. 196-98.
94. Note 4 supra.
95. Decision, supra note 7, at 20. 
Convention cannot be said to be obsolete, but it went on to emphasise that this finding did not mean that the court regarded itself as "debarred from taking any account ... of recent developments in customary law. On the contrary, the Court [had] no doubt that it should take due account of the evolution of the law of the sea in so far as . . . may be relevant"96 to the case.

If, following the court, one endeavours to take due account of the evolution of the law of the sea, the obvious points of reference are to be found in Articles 76 and 83 of the Informal Composite Negotiating Text ${ }^{97}$-the latest fruits of the UNCLOS labours.

Article 76 of the text defines the continental shelf as follows:

The continental shelf of a coastal State comprises the sea-bed and subsoil of the submarine areas that extend beyond its territorial sea throughout the natural prolongation of its land territory to the outer edge of the continental margin, or to a distance of 200 nautical miles from the baselines from which the breadth of the territorial sea is measured where the outer edge of the continental margin does not extend up to that distance.98

Though the concept of natural prolongation is incorporated in this definition, it is irrelevant in the present context because this Article essentially refers to the outer limit of the continental shelf rather than to its delimitation between neighbouring States. Similarly, the text of Article 83(1) offers no assistance. It simply provides that: "The delimitation of the continental shelf between adjacent or opposite States shall be effected by agreement in accordance with equitable principles, employing, where appropriate, the median or equidistance line, and taking account of all the relevant circumstances." 99 There is thus no mention of natural prolongation.

\section{Conclusion}

It seems fair to conclude that the decision of the Court of Arbitration serves only to confirm that the concept of natural prolongation may not properly be regarded as relevant to the delimitation of boundaries of the continental shelf between adjacent or opposite States except possibly in a situation where a major geological discontinuity runs laterally seaward from the

96. Id. para. 48.

97. U.N. Docs. A/Conf. 62/WP. 10 \& Add. 1, reprinted in 8 UNCLOS III OR 1, and in 16 INT'L LEGAL MATERIALS 1099 (1977).

98. Id. art. 76.

99. Id. art. $83(1)$. 
vicinity of the coastal terminus of the land boundary of adjacent States or lies between the coasts of opposite States.

\section{VI. "Special Circumstances" and "Equitable Principles"}

It will be recalled that the I.C.J. found that the application of the equidistance rule, as incorporated in Article 6 of the Geneva Convention, was not obligatory as between the parties in the North Sea Continental Shelf Cases.100 It was, therefore, unnecessary for the court to consider whether special circumstances existed in that case or to concern itself with the scope of the concept of special circumstances. In its exposition of the corresponding rules of international customary law, however, it was apparent that the role of equity, as conceived by the court, was similar to that of the concept of special circumstances. Since the court delivered its judgment in 1969, it has frequently been assumed that the equitable factors that would justify a boundary other than an equidistant boundary under international customary law are the same as the factors that would constitute special circumstances under Article 6 of the Geneva Convention. As will be seen, the Court of Arbitration in the Anglo-French Continental Shelf Case seems to sympathise with this view. The purposes of part VI of this article are to reconsider in the light of the decision of the Court of Arbitration (1) the meaning of special circumstances in the sense of Article 6 and of the corresponding rules of international customary law as laid down by the I.C.J. in the North Sea Cases and (2) the relationship between the two.

To place the views of the Court of Arbitration in proper perspective, it is necessary first to review the judgment of the I.C.J. in the North Sea Cases and to examine the meaning of "special circumstances" in the Geneva Convention.

\section{A. The North Sea Continental Shelf Cases}

The court held that

delimitation is to be effected by agreement in accordance with equitable principles, and taking account of all the relevant circumstances, in such a way as to leave as much as possible to each Party all those parts of the continental shelf that constitute a natural prolongation of its land territory into and under the sea, without encroachment on the natural prolongation of the land territory of the other. 101

The court dealt with the nature of these "equitable principles" and "relevant circumstances" at some length. First, it said:

[T] here is no legal limit to the considerations which States may take account of for the purpose of making sure that they apply equitable proce-

100. [1969] I.C.J. para. 101.

101. Id. 
dures, and more often than not it is the balancing-up of all such considerations that will produce this result rather than reliance on one to the exclusion of all others. The problem of the relative weight to be accorded to different considerations naturally varies with the circumstances of the case. 102

The court went on to add that:

In balancing the factors in question it would appear that various aspects must be taken into account. Some are related to the geological, others to the geographical aspect of the situation, others again to the idea of the unity of any deposits. These criteria, though not entirely precise, can provide adequate bases for decision adapted to the factual situation.103

Subsequently, the court specified in more detail these various "factors" that were to be taken into account in the course of the negotiations, referring first to "the general configuration of the coasts of the Parties, as well as the presence of any special or unusual features."104 Of this geographical factor, the court had earlier said:

[I]t is . . . necessary to examine closely the geographical configuration of the coastlines of the countries whose continental shelves are to be delimited. This is one of the reasons why the Court does not consider that markedly pronounced configurations can be ignored; for, since the land is the legal source of the power which a State may exercise over territorial extensions to seaward, it must first be clearly established what features do in fact constitute such extensions.105

The second factor specified by the court was "so far as known or readily ascertainable, the physical and geological structure, and natural resources, of the continental shelf areas involved."106 Of this geological factor, the court had earlier observed that:

[I] $t$ can be useful to consider the geology of that shelf in order to find out whether the direction taken by certain configurational features should influence delimitation because, in certain localities, they point-up the whole notion of the appurtenance of the continental shelf to the State whose territory it does in fact prolong. ${ }^{107}$

In relation to natural resources, the court did not regard preservation of unity of deposits as a major factor but merely "a factual element which it is reasonable to take into consideration in the course of the negotiations." 108

Third, the court indicated that the factors to be taken into account should include

the element of a reasonable degree of proportionality, which a delimita-

102. Id. para. 93 .

103. Id. para. 94.

104. Id. para. 101.

105. Id. para. 96.

106. Id. para. 101.

107. Id. para. 95.

108. Id. para. 97. 
tion carried out in accordance with equitable principles ought to bring about between the extent of the continental shelf areas appertaining to the coastal State and the length of its coast measured in the general direction of the coastline, account being taken for this purpose of the effects, actual or prospective, of any other continental shelf delimitations between adjacent States in the same region. 109

In another passage the court referred to this proportionality factor as follows:

[T] he element of a reasonable degree of proportionality which a delimitation effected according to equitable principles ought to bring about between the extent of the continental shelf appertaining to the States concerned and the lengths of their respective coastlines,--these being measured according to their general direction in order to establish the necessary balance between States with straight, and those with markedly concave or convex coasts, or to reduce very irregular coastlines to their truer proportions. ${ }^{110}$

It is submitted that the analysis of "special circumstances" given below shows that this concept is much more limited in scope and less open to arbitrary concretisation than the principle of equity as interpreted by the court.

\section{B. The Meaning of "Special Circumstances" in Article 6 of the Geneva Convention}

The object of this section is to clarify the intended scope of "special circumstances." On analysis of the evidence, it is possible to identify factors clearly falling within this category, to eliminate other factors, and to establish guidelines for the evaluation of claims made for yet others.

At the outset, it should be made clear that there can be no question of regarding the concept as being so vague and all-embracing as to justify settlement of disputes ex aequo et bono. Although Professor Spiropoulos stated, when he introduced the term into the International Law Commission (ILC) debate,111 that his formula would enable arbitrators to settle disputes ex aequo et bono, 112 subsequent developments indicate quite clearly that this view was rejected.113

109. Id. para. 101.

110. Id. para. 98.

111. Summary Records of the 204th Meeting, [1953] 1 Y.B. INT't L. CoMm'N 124, 130, U.N. Doc. A/CN.4/SER.A/1953 (1959).

112. Summary Records of the 205th Meeting, [1953] 1 Y.B. INT'L L. CoMM'N 130, 132, U.N. Doc. A/CN.4/SER.A/1953 (1959).

113. See Professor Lauterpacht's remarks, $i d$. at 131; the response of States referred to in Comments by Governments on the draft articles on the continental shelf and related subjects prepared by the International Law Commission at its third session in 1951, Report of the International Law Commission to the General Assembly, 8 U.N. GAOR, Supp. (No. 9) 42, U.N. Doc. A/2456 (1953), reprinted in [1953] 2 Y.B. INT'L L. COMM'N 200, 241, U.N. Doc. A/CN.4/SER.A/1953/Add. 1 (1959); rejection by the UNCLOS I Fourth Committee of the Netherlands proposal to empower the I.C.J. to decide ex aequo et bono on existence of special circumstances, 
Given that the matter is not to be determined ex aequo et bono, it is clearly desirable that the rule should be as specific as possible-hence the plea by Professor Lauterpacht for a full explanation in the commentary, together with an enumeration of specific instances; ${ }^{114}$ hence, too, the statement of the Yugoslav delegate at Geneva that: "The question was where and how such special circumstances were enumerated in international law and who could be charged with interpreting their application."115 As Judge Sørensen put it, "[ $t]$ he clearer the ad hoc rule, the more automatic its application, the less the seed of discord is sown."116

The evidence may be marshalled below under four heads.

\section{Geographical Considerations}

It is clear from the record that exceptional geographical circumstances constitute the main category of special circumstances. Even before the term had been introduced in the ILC, Professor Hudson cited an International Law Association (ILA) report, dated 1950, as having suggested that "factors such as the configuration of the coastline" should be taken into consideration.117 Similarly, the comments on draft Article 7 in the 1953 ILC report referred to the need to make provision for "departures necessitated by any exceptional configuration of the coast."118

Again, at the 1958 Geneva Conference, the Venezuelan delegate referred to special circumstances "such as were frequently imposed by geography."119 Miss Whiteman (United States) spoke of the need to retain the special circumstances provision because of the "great variety of complex geographical situations."120

The most frequent cause of such an exceptional configuration is

6 UNCLOS I OR, C.4 (35th mtg.) 102, 106, U.N. Doc. A/Conf. 13/42 (1958); Netherlands: proposal, U.N. Doc. A/Conf. 13/C.4/L.62 (1958), reprinted in 6 UNCLOS I OR, C. 4 Annexes 143, U.N. Doc. A/Conf. 13/42 (1958); and [1969] I.C.J. para. 88.

114. Summary Records of the 204th Meeting, [1953] 1 Y.B. INT'L L. COMM'N 124, 128, 129-30, U.N. Doc. A/CN.4/SER.A/1953 (1959).

115. 6 UNCLOS I OR, C.4 (31st mtg.) 91, 91, U.N. Doc. A/Conf. $13 / 42$ (1958).

116. North Sea Continental Shelf Cases, [1969] I.C.J. 3, 256 (Sфrensen, J., dissenting).

117. Summary Records of the 69th Meeting, [1950] 1 Y.B. INT'L L. CoMm'N 231, 233, U.N. Doc. A/CN.4/SER.A/1950 (1958).

118. Report of the International Law Commission to the General Assembly, 8 U.N. GAOR, Supp. (No. 9) 16, U.N. Doc. A/2456 (1953), reprinted in [1953] 2 Y.B. INT'L L. COMM'N 200, 216, U.N. Doc. A/CN.4/SER.A/1953/Add. 1 (1959).

119. 6 UNCLOS I OR, C.4 (31st mtg.) 91, 92, U.N. Doc. A/Conf. 13/42 (1958).

120. Id. (32d mtg.) 93,95 . 
the presence of islands on the continental shelf. Professor François had already acknowledged in 1953121 that a departure from the general rule would be necessary, for example, when a small island opposite one State's coast belonged to another State. Accordingly, the commentary to draft Article 7 of the 1953 ILC report referred specifically to "the presence of islands" as a possible cause of special circumstances. 122

If there was agreement that islands might constitute a special circumstance, there was no agreement as to how account should be taken of their presence. Commander Kennedy (United Kingdom), ${ }^{123}$ supported by Miss Whiteman,124 proposed in the Geneva Conference that islands should be treated on their merits. Very small islands or sand cays on a continuous continental shelf and outside the belt of territorial sea might be neglected as base points for measurement and have only their own appropriate territorial sea. Iran ${ }^{125}$ and Italy ${ }^{126}$ favoured ignoring all islands on the continental shelf, but Miss Whiteman found this proposal too extreme "in view of the great variety of size, grouping and position of islands."'127

Another proposal was that islands should be treated like enclaves, with separate continental shelf areas proportional to their size, thereby leaving unaffected the division of the area between opposite coasts into equal parts by means of the median line.128 State practice provides a number of examples of the way in which deviations from a median-line delimitation have been made to allow for special circumstances created by islands. ${ }^{129}$

121. Summary Records of the 204th Meeting, [1953] 1 Y.B. INT'L L. COMM'N 124, 128, U.N. Doc. A/CN.4/SER.A/1953 (1959). See also the remarks of Professor Spiropoulos, Summary Records of the 208th Meeting, [1953] 1 Y.B. INT'L L. CoMM'N 150, 152, U.N. Doc. A/CN.4/SER.A/1953 (1959).

122. Report of the International Law Commission to the General Assembly, 8 U.N. GAOR, Supp. (No. 9) 16, U.N. Doc. A/2456 (1953), reprinted in [1953] 2 Y.B. INT'L L. COMM'N 200, 216, U.N. Doc. A/CN.4/SER.A/1953/Add. 1 (1959).

123. 6 UNCLOS I OR, C.4 (32d mtg.) 93, 93, U.N. Doc. A/Conf. 13/42 (1958).

124. Id. at 95 .

125. Id. (31st mtg.) 91, 92; Iran: proposal, U.N. Doc. A/Conf. 13/C.4/L.60 (1958), reprinted in 6 UNCLOS I OR, C.4 Annexes 142, U.N. Doc. A/Conf. 13/42 (1958).

126. 6 UNCLOS I OR, C.4 (32d mtg.) 93, 93, U.N. Doc. A/Conf. 13/42 (1958); Italy: proposal, U.N. Doc. A/Conf. 13/C.4/L.25/Rev. 1 (1958), reprinted in 6 UNCLOS I OR, C.4 Annexes 133, U.N. Doc. A/Conf. 13/42 (1958). See also UNESCO, Scientific Considerations Relating to the Continental Shelf, U.N. Doc. A/Conf. 13/2 \& Add. 1 (1957), reprinted in 1 UNCLOS I OR, PREPARATORY DOCUMENTS 39, para. 12, U.N. Doc. A/Conf. 13/37 (1959).

127. 6 UNCLOS I OR, C.4 (32d mtg.) 93, 95, U.N. Doc. A/Conf. 13/42 (1958).

128. See E. BROWN, supra note 60 , at 64 n.142.

129. The position of islands is considered in L. HENKIN, LAW FOR THE SEA's MiNeral RESOUReEs 43 n.129 (1968); Ely, Seabed Boundaries Between Coastal States: The Effect to be Given Islets as 'Special Circumstances,' 6 INT'L LAw. 219 (1972), Goldie, The International Court of Justice's 'Natural Prolongation' and the Conti- 
A second example of exceptional geographical circumstances that seems to have been accepted as constituting a special circumstance is well illustrated by the Iranian coast. The existence of extensive sedimentary mud flats apparently makes identification of the low-water line very difficult. The Iranian delegation in the Geneva Conference accordingly sought to have it specifically provided in Article 72 that in such circumstances the boundary of the continental shelf should be measured from the high-water mark. ${ }^{130}$ Commander Kennedy remarked that the high-water mark was also subject to change, ${ }^{131}$ and Miss Whiteman rejected the plea for specific reference in the Convention. However, Miss Whiteman also described such cases as being in any event fully covered by the reference to special circumstances.132 Moreover, when the Iranian government ratified the Geneva Convention subject to a reservation designed to ensure such an interpretation of "special circumstances," no protest was made.133

The next question that must be considered is this: In the absence of islands or mud flats, what type of exceptional configuration may constitute a special circumstance? Two extreme views may indicate the scope for disagreement.

In the German pleadings in the North Sea Cases it was argued that:

\footnotetext{
"Special circumstances" are always present should the situation display not inconsiderable divergencies from the normal case. The normal case, in which the application of the equidistance method leads to a just and equitable apportionment, is a more or less straight coastline, so that the areas of the shelf apportioned through the equidistance boundary more or less correspond to the shorelines (façades) of the adjacent States. Should this not be the case, and should therefore no equitable and appropriate solution result, the clause of the "special circumstances" applies.134
}

nental Shelf Problem of Islands, [1973] 4 NETH. Y.B. INT'L L. 237; Whiteman, Conference on the Law of the Sea: Convention on the Continental Shelf, 52 AM. J. INT'L L. $629,651-53$ (1958).

130. 6 UNCLOS I OR, C.4 (31st mtg.) 91, 92, U.N. Doc. A/Conf. 13/42 (1958).

131. Id. (32d mtg.) $93,93$.

132. Id. at 95 .

133. Counter-Memorial of Denmark, 1 North Sea Continental Shelf Cases, I.C.J. Pleadings 157, 230-33 (1968).

134. Memorial of the Federal Republic of Germany, 1 North Sea Continental Shelf Cases, I.C.J. Pleadings 13, 68-69 (1968). See also Oral Pleadings, 2 North Sea Continental Shelf Cases, I.C.J. Pleadings 7, 50:

Any geographical factor which diverts the course of the equidistance boundary between two States in such a manner as to cause the allocation of considerable areas of the continental shelf to one State which is necessarily classified as a natural continuation of the territory of a second State, 
The court's adoption of the theory of macrogeography, advanced by German counsel, is similar. Thus, as has been seen, "the factors to be taken into account" in the course of negotiations between neighbouring States "are to include"

the element of a reasonable degree of proportionality, which a delimitation carried out in accordance with equidistance principles ought to bring about between the extent of the continental shelf areas appertaining to the coastal State and the length of its coast measured in the general direction of the coastline, account being taken for this purpose of the effects, actual or prospective, of any other continental shelf delimitations between adjacent States in the same region.135

This proposition is not very far removed from Judge Padilla Nervo's finding that:

[I]t appears that this particular case, that of an internal sea, was not contemplated when the text of Article 6 was drafted. Neither paragraph 1 nor paragraph 2 of Article 6 have made provision for the overlaps which may arise from the simultaneous existence of median and lateral equidistance lines where there are both opposite and adjacent States in a particular internal sea. It appears therefore that the case of the North Sea, so far as the situation of the Parties to the present dispute is concerned, could be deemed a case in which special circumstances exist.136

These views mark one extreme. At the other extreme is the view of Judge Koretsky who, in his dissenting opinion, held that:

[E]ven if the presence of special circumstances is observed and confirmed, those special circumstances can only justify a deviation from the normal line if they are located comparatively near to the landward starting-point of the boundary line of the continental shelf adjacent to the territories of the two (and only two) adjacent States .... All "macrogeographical" considerations are entirely irrelevant, except in the improbable framework of a desire to redraw the political map of one or more regions of the world. 137

This view perhaps goes too far. It is submitted that the most reasonable interpretation of the scope of "special circumstances" in relation to exceptional geographical configuration is that advanced in the pleadings on behalf of the Danish and Netherlands governments and summed up in the following passages:

The legal concept of special circumstances has found expression in the Convention in the form that special circumstances are to be taken into account only when they justify another boundary line. If Article 6 is applied as a rule of law this must necessarily mean that the correction of the equidistance principle which the clause cleariy intends, can take place only if deviation from the equidistance line is justified towards both States-i.e., the State which "gains" and the State which "loses" by the correction.

...

... It seems thus legitimate to interpret the "special circumstances" clause to the effect that it can be invoked against a State whose continental shelf boundary under the equidistance principle reflects projecting geo.

then such a factor must be regarded as a special circumstance within the meaning of Article 6, paragraph 2 of the Convention.

135. [1969] I.C.J. 3, para. 101.

136. Id. at 90 (emphasis original) (Padilla Nervo, J., separate opinion).

137. Id. at 162 (emphasis original) (Koretsky, J., dissenting). 
graphical features (primarily certain islands and peninsulas) whereas it cannot be applied against a State whose continental shelf has a solid geographical connection with the territory of that State thereby constituting a natural continuation of the territory of the State in conformity with the general geographical situation. ${ }^{138}$

Subject to reservations about the use of the word "natural" in this context, this proposition seems closely in accord with both the language of Article 6 and the record reviewed above.

\section{Mineral Deposits}

References have frequently been made to the economic value of proven deposits of minerals, or to the possession of special mineral exploitation rights, or to the unity of deposits as being factors that might constitute special circumstances.

Professor Hudson alluded in the IIC to "the economic value of proven deposits of minerals" as another factor suggested in the ILA Committee's 1950 report as being relevant to the issue of delimitation.139 It is noticeable, however, that no reference to mineral deposits was incorporated in the commentary to the ILC report in either its 1953 or its 1956 versions. Because the commentary was in part at least intended to satisfy Professor Lauterpacht's request for greater clarity as to the scope of special circumstances, 140 it would seem reasonable to suppose that the IIC did not intend to extend the concept to cover this question.

Professor Mouton, in his Hague Lectures in 1954, referred to the existence of common deposits situated across the mathematical boundary as constituting a special circumstance. 141 Further references are to be found in the Geneva Conference debates. Commander Kennedy, for example, referred to the special circumstance of "the possession by one of the two States concerned of special mineral exploitation rights." 142

The court in the North Sea Cases mentioned natural resources "so far as known or readily ascertainable" as a factor to be taken into account in the negotiations between the parties. ${ }^{143}$ Why this

138. Common Rejoinder of Denmark and the Netherlands, 1 North Sea Continental Shelf Cases, I.C.J. Pleadings 453, 526-27 (1968) (emphasis original).

139. Summary Records of the 69th Meeting, [1950] 1 Y.B. INT'L L. COMM'N 231, 233, U.N. Doc. A/CN.4/SER.A/1950 (1958).

140. See text accompanying note 114 supra.

141. Mouton, The Continental Shelf, 85 Hague REcuen 420 (1954).

142. 6 UNCLOS I OR, C.4 (32d mtg.) 93, 93, U.N. Doc. A/Conf. 13/42 (1958). See also Mr. Carbajal (Uruguay), id. at 95.

143. [1969] I.C.J. 3, para. 101. 
should have been included in an enumeration of factors that would contribute to an equitable solution is not clear. It goes without saying that the parties are free, on a consensual basis, to make whatever provisions they please for the economic or convenient exploitation of a common deposit, either by joint exploitation or otherwise. The existence of the deposit would scarcely seem to constitute a "special circumstance," however, entitling a coastal State to demand a deviation from the equidistance line.

The only situation that would seem to justify reference to natural resources as constituting special circumstances is that where a coastal State had acquired exclusive rights to such resources independently of, and prior to, the development of the continental shelf doctrine. For example, if a State's exclusive right to exploit a sedentary fishery (falling within the definition of natural resources in the Geneva Convention) ${ }^{144}$ on the bed of the geological continental shelf had been established prior to 1945 , there might be an argument for saying, with Judge Jessup, 145 that it would be right to apply the Grisbadarna principle146 of refraining from modifying a settled state of things-or of regarding the existence of the sedentary fishery as a historical special circumstance. ${ }^{147}$

Apart from the above, Judge Ammoun is surely right in holding that "if the preservation of the unity of deposit is a matter of concern to the Parties, they must provide for this by a voluntary agreement ...., and this does not fall within the category of a factor or rule of delimitation."148

\section{Navigation and Fishing Rights}

Mention has already been made of the possibility that a State may possess exclusive rights to exploit a continental shelf resource that pre-dates the doctrine of the continental shelf and thus constitutes a special circumstance in relation to its delimitation. 149

144. I.e., "organisms which, at the harvestable stage, either are immobile on or under the seabed or are unable to move except in constant physical contact with the seabed or the subsoil." Geneva Convention, supra note 4, art. 2(4).

For a discussion of the position of king crabs on the continental shelf off Alaska, see Johnson, Fishery Developments in the Pacific, in DEVELOPMENTS IN THE LAW OF THE SEA 1958-1964, at 133, 143-45 (1965). See also Goldie, Sedentary Fisheries and Article 2(4) of the Convention on the Continental Shelf-A Plea for a Separate Regime, 63 AM. J. INT'L L. 86, $92-93$ (1969); Windley, International Practice Regarding Traditional Fishing Privileges of Foreign Fishermen in Zones of Extended Maritime Jurisdiction, 63 AM. J. INT'L L. 490 (1969).

145. [1969] I.C.J. 3, 79 (Jessup, J., separate opinion).

146. See note 159 and accompanying text infra.

147. See § VI(B)(4) infra.

148. [1969] I.C.J. 3, 149 (Ammoun, J., separate opinion).

149. See text accompanying note 144 supra. 
Apart from this situation, it seems likely that many of the references to navigation and to fishing rights recorded below are the result of rather automatic repetition of propositions first stated in relation to the somewhat different problem of delimiting the territorial sea.

The origin of many of the subsequent references appears to have been the following passage in the Answer given by the Committee of Experts to the ILC Rapporteur's question on delimitation of the territorial sea between opposite coasts: "There may, however, be special reasons, such as navigation and fishing rights, which may divert the boundary from the median line."150

Although, as has been seen, Professor François made it clear151 that these remarks referred only to the territorial sea, and that navigation and fishing rights in the continental shelf area were protected by Article 5 of the ILC's draft,152 it remains true that in the commentary to Article 72 (both in the 1953 and the 1956 ILC reports), reference was made to departures from the equidistance line necessitated by the presence of navigable channels. 153 Moreover, Commander Kennedy, a distinguished member of the Committee of Experts and a member of the United Kingdom delegation to UNCLOS I, specifically referred in the UNCLOS Fourth Committee to "the possession by one of the two States concerned of ... fishery rights, or the presence of a navigable channel" as being "[o]ther types of special circumstances."154

Judge Padilla Nervo went further: "In addition to special situations of a technical nature-navigable channels, cables, safety or defence requirements, protection of fisheries (fish banks), indivisible deposits of mineral oil or natural gas, etc.-special geographical situations such as special coastal configurations have been regarded as special circumstances."155

150. Counter-Memorial of Denmark, 1 North Sea Continental Shelf Cases, I.C.J. Pleadings 157, 257 (1968).

151. Summary Records of the 204th Meeting, [1953] 1 Y.B. INT'L L. CoMm'N 124, 127, U.N. Doc. A/CN.4/SER.A/1953 (1959).

152. See now Geneva Convention, supra note 4, art. 5.

153. See Report of the International Law Commission to the General Assembly, 11 U.N. GAOR, Supp. (No. 9) 44, U.N. Doc. A/3159 (1956), reprinted in [1956] 2 Y.B. INT'L L. CoMM'N 253, 300, U.N. Doc. A/CN.4/SER.A/1956/Add. 1 (1957); Report of the International Law Commission to the General Assembly, 8 U.N. GAOR, Supp. (No. 9) 16, U.N. Doc. A/2456 (1953), reprinted in [1953] 2 Y.B. INT'L L. CoMM'N 200, 216, U.N. Doc. A/CN.4/SER.A/1953/Add. 1 (1959).

154. 6 UNCLOS I OR, C.4 (32d mtg.) 93, 93, U.N. Doc. A/Conf. 13/42 (1958).

155. [1969] I.C.J. 3, 93 (Padilla Nervo, J., separate opinion). This passage is in 
Despite these references, the truth seems to be that during the earlier period of the development of the continental shelf doctrine, it was recognised (1) that delimitation of the continental shelf between neighbouring States should take account of special coastal configurations and (2) that provision must be made for the protection of existing interests such as fishing, navigation, and submarine cables. In the course of the later development of the doctrine, however, provision was made for the latter interests by specific inclusion in the Geneva Convention.156 It is precisely the function of Articles 3 to 5 of the Convention to effect a reconciliation between these various interests and those of the coastal State. ${ }^{157}$

\section{Historical Special Circumstances}

Although Article 6 of the Geneva Convention on the Continental Shelf lacks the specific references to historical special circumstances that are to be found in the Territorial Sea Convention,158 it would seem that the general term "special circumstances" was intended to embrace such circumstances.

In reality, however, historical special circumstances will very seldom be relevant to delimitation of the continental shelf as distinct from delimitation of the territorial sea. Thus, for example, when certain waters are recognised as possessing the status of a historic bay or of other historic waters, the baseline of the territorial sea will be extended to encompass these waters. The continental shelf delimitation, however, will be made not by reference to historical special circumstances but rather to the baseline of the territorial sea determined by those historical circumstances.

Once again, however, the position of sedentary fisheries may re. quire separate consideration. If title has been acquired to such a fishery (or indeed to any other natural resource of the seabed or

fact an unacknowledged quotation from the Memorial of the Federal Republic of Germany, 1 North Sea Continental Shelf Cases, I.C.J. Pleadings 13, 69 (1968).

156. Supra note 4, arts. 4-5.

157. But see the French reservation to $i d$. art. 6, Multuateral Treaties in RESPECT OF Which the Secretary-General Performs Depositary Functions, List of Signatures, Ratifications, etc. as at 31 December 1977, at 540, U.N. Doc. ST/LEG/SER.D/11 (1978). It would appear that France interprets "special circumstances" as covering fishing and navigation interests.

158. Article 12 of the Convention on the Territorial Sea and the Contiguous Zone, done Apr. 29, 1958, [1964] 15 U.S.T. 1606, T.I.A.S. No. 5639, 516 U.N.T.S. 205, refers to variations from the equidistance line "by reason of historic title or other special circumstances," and Article 4(4), id., permits account to be taken of "economic interests peculiar to the region concerned, the reality and the importance of which are clearly evidenced by a long usage" - but only in determining particular baselines in a straight-baseline system justified by the geographical configuration of the coast. 
subsoil) in the area of what is now recognised as the continental shelf but prior to the establishment of that doctrine, then it is arguable that the preservation of such rights should require a modification of the equidistance line of delimitation.

Judge Jessup drew attention to an intermediate position in his separate opinion in the North Sea Cases. He referred to the conclusions of the Arbitral Tribunal in the Grisbadarna Case159 that

in the law of nations, it is a well established principle that it is necessary to refrain as far as possible from modifying the state of things existing in fact and for a long time; that principle has a very particular application when private interests are in question, which, once disregarded, can not be preserved in an effective manner even by any sacrifices of the State, to which those interested belong . . . .160

Judge Jessup commented that "[c]onsidering the rapidity of the progress of exploitation in the petroleum industry in the North Sea, no restrictive limit should be placed on the elapsed time."161 He admitted that the

existence of actual drilling or exploitation in a certain place cannot be considered in the present circumstances to base a title on prescription, or on prior use or occupation; nor is it to be assimilated to "historic title" which is mentioned as a "special circumstance" in Article 12 of the 1958 Convention on the Territorial Sea. 162

Nevertheless he thought that the parties "might well bear in mind" the provisions in the Anglo-Venezuelan Treaty of 1897 that "such effect shall be given to such occupation as reason, justice, the principles of international law, and the equities of the case shall . . . require."163

Certain alleged cases of historical special circumstances were referred to in the pleadings in the North Sea Cases. Thus it was argued in the Netherlands Counter-Memorial that part of the maritime boundary between Finland and the Soviet Union laid down in the Agreement of May, 1965,164 being governed by the provisions of the Peace Treaties of 1940165 and 1947,166 reflected a special circumstance already existing when the Agreement of 1965

159. (Norway v. Sweden), [1916] 1 Hague Ct. Rep. (Scott) 121 (1909).

160. [1969] I.C.J. 3, 79-80 (Jessup, J., separate opinion).

161. Id. at 80.

162. Id.

163. Id.

164. Agreement on Boundaries of Sea Waters and Continental Shelf in the Gulf of Finland, May 20, 1965, Finland-Soviet Union, 566 U.N.T.S. 31, reprinted in 6 INT'L LEgaL Materials 727 (1967).

165. Peace Treaty of Mar. 12, 1940, Finland-Soviet Union.

166. Treaty of Peace with Finland, signed Feb. 10, 1947, 48 U.N.T.S. 203. 
was concluded.167

Similarly, the two most landward points of the boundary lines established by the Agreement of July 24, 1968, between Norway and Sweden 168 were fixed by reference to the line established by the Grisbadarna award. As the Common Rejoinder of the Danish and Netherlands governments put it, "in other words, by refer. ence to a historic 'special circumstance." "169

In this sense, the German view that "special circumstances" include "any exceptional delimitations of territorial waters"170 is similar.

\section{Conclusion}

While it would obviously be wrong, on the basis of the above evidence, to attempt to draw up a closed list of cases of special circumstances, it would be equally unjustifiable to ignore the fact that this evidence clearly suggests that the concept of "special circumstances" is much more limited in scope than the principle of equity as interpreted by the court in the North Sea Cases. It is submitted that the above analysis provides a set of guidelines by reference to which it may be ascertained whether considerations invoked by a party as constituting special circumstances may properly be so regarded.

\section{The Anglo-French Continental Shelf Case}

1. Relationship Between Article 6 and International Customary Law

In its Decision in the Anglo-French Continental Shelf Case, the Court of Arbitration referred extensively both to the rules of international customary law as interpreted by the I.C.J. in the North Sea Continental Shelf Cases and to the provisions of Article 6 of the Geneva Convention. In several passages, the Court of Arbitration indicated its view on the relationship between the two.

It had been argued by France that the Geneva Convention was now obsolete. The court rejected this contention but, having de-

167. Counter-Memorial of the Netherlands, 1 North Sea Continental Shelf Cases, I.C.J. Pleadings 307, para. 96 (1968).

168. Common Rejoinder of Denmark and the Netherlands, 1 North Sea Continental Shelf Cases, I.C.J. Pleadings 453, 554 (1968).

169. Id. para. 64 .

170. 6 UNCLOS I OR, C.4 (33d mtg.) 96, 98, U.N. Doc. A/Conf. 13/42 (1958) (remarks of Prof. Munch). For argument that the boundaries fixed in the agreements between Germany and the Netherlands (December 1, 1964) and Germany and Denmark (June 9, 1965) take account of such a special circumstance, see CounterMemorial of the Netherlands, 1 North Sea Continental Shelf Cases, I.C.J. Pleadings 307, para. 100 (1968). 
clared that the Convention was in force between the parties, went on to say that this finding
does not mean that it regards itself as debarred from taking any account in these proceedings of recent developments in customary law. On the contrary, the Court has no doubt that it should take due account of the evolution of the law of the sea in so far as this may be relevant in the con- text of the present case. 171

The court spelled out the implications of this statement in more detail in a later passage:
[T] he Court considers that Article 6 is applicable in principle, to the de- limitation of the continental shelf as between the Parties under the Arbi- tration Agreement. This does not, however, mean that the Court considers the rules of customary law discussed in the judgment in the North Sea Continental Shelf cases to be inapplicable in the present case. As already pointed out, the provisions of Article 6 do not define the condi- tions for the application of the equidistance-special circumstances rule; moreover, the equidistance-special circumstances rule and the rules of customary law have the same object-the delimitation of the boundary in accordance with equitable principles. In the view of this Court, therefore, the rules of customary law are a relevant and even essential means both for interpreting and completing the provisions of Article 6.172

It is of course true that circumstances that would constitute "special circumstances" in accordance with the guidelines analysed above would also constitute "factors creative of inequity" under international customary law. It is submitted, however, that the converse is not true. Factors that might be held to be creative of inequity in accordance with the rules expounded by the I.C.J. would not necessarily fall within the narrower guidelines relating to special circumstances under Article 6 . Thus, the fact that the Court of Arbitration could truly say that the effect of applying or of not applying Article 6 would make very little, if any, practical difference to the boundary line in the circumstances of this case ${ }^{173}$ proves nothing about the relationship between the rules of Article 6 and those of international customary law.

In another passage, the court said that: "The double basis on which both Parties put their case regarding the Channel Islands confirms the Court's conclusion that the different ways in which the requirements of 'equitable principles' or the effects of 'special circumstances' are put reflect differences of approach and terminology rather than of substance."174

171. Decision, supra note 7, para. 48.

172. Id. para. 75.

173. Id. para. 65 .

174. Id. para. 148. 
Once again, this may be an acceptable statement in the circumstances of this case. If it was intended to be of general validity, however, it goes too far. There are grounds for believing that the court did intend it to be of general application. Thus, it not only regarded the rules of international customary law as "essential means both for interpreting and completing the provisions of Article 6";175 it also referred, in connection with the special circumstances rule, to considerations that clearly do not fall within the guidelines identified above.

The court had come to the prima facie view that the existence of the Channel Islands close to the French coast, if permitted to divert the course of the mid-Channel median line, would effect a radical distortion of the boundary, creative of inequity. It went on to test this prima facie conclusion by applying the equidistancespecial circumstances rule of Article 6. It was concerned, in this connection, to see whether a departure from the median line was "justified" in relation to both parties and in the light of all the "relevant circumstances."176 Among the "relevant circumstances" invoked by the United Kingdom and accepted by the court "as carrying a certain weight" were the following: (1) the particular character of the Channel Islands as populous islands of a certain political and economic importance, (2) the close ties between the Islands and the United Kingdom, (3) the latter's responsibility for their defence and security, and (4) the impossibility of the Islands having any appreciable area of continental shelf except in the open waters to their west and north. ${ }^{177}$

While it is true that these circumstances were allowed to have only a very minor effect on the boundary line, the court's reasoning does indicate how wide it considered the category of factors relevant to special circumstances to be. In the writer's opinion, Professor Briggs was right to express his concern-in his separate declaration-that the court's interpretation of Article 6 "constitutes some threat that the rule of positive law expressed in Article 6 will be eroded by its identification with subjective equitable principles, permitting attempts by the Court to redress the inequities of geography."178

The approach of the Court of Arbitration is particularly well illustrated by its treatment of defence and security interests. The French government had argued that the application of the equidistance method in the Channel Islands region would be inequita-

175. Id. para. 75 .

176. Id. para. 197.

177. $I d$.

178. Id. at 236. 
ble, inter alia, because it would involve severing the continental shelf of France into two zones separated by a United Kingdom zone. This severance, in turn, would be prejudicial to the vital interests of France in the security and defence of its territory. France referred in particular to the fact that it would be deprived of any right to control activities in the whole Hurd Deep Zone and that this deprivation would involve serious inconveniences and risks for French submarines stationed at Cherbourg as well as affecting the French Republic's military supervision of the approaches to its territory. 179

The United Kingdom, though as a matter of advocacy invoking similar defence and navigational interests for itself and seeking to refute the factual basis of the French claim, argued that France's security, defence, and navigational interests were not entitled to be given weight. The United Kingdom pointed out that the French argument did not take account of the legal protection given to those interests by the regime of the continental shelf itself, especially Articles 3 to 5 of the Geneva Convention. ${ }^{180}$

The Court of Arbitration took an intermediate position, In its view,
the weight of such considerations in this region is, in any event, somewhat diminished by the very particular character of the English Channel as a major route of international maritime navigation serving ports outside the territories of either of the Parties. Consequently, they cannot be regarded by the Court as exercising a decisive influence on the delimitation of the boundary in the present case. They may support and strengthen, but they cannot negative, any conclusions that are already indicated by the geo- graphical, political and legal circumstances of the region which the Court has identified.181

In other words, the court was prepared in principle to regard such matters as relevant to the question of equity or special circumstances, though in the context of this case it allowed very little weight to be attributed to them.

In the writer's opinion, the above analysis of the meaning of special circumstances suggests that such matters do not come within the scope of this concept.

179. Id. paras. $161-63$.

180. Id. paras. 175-76.

181. Id. para. 188. 
2. The Status of the Principle of Equidistance Under Article 6 and the Question of the Burden of Proof of Special Circumstances

The Court of Arbitration was obliged to consider the question posed in the heading above because of the United Kingdom's contention that the onus of proof lay upon France to show that special circumstances existed. Before examining the court's opinion, it is enlightening first to review the travaux préparatoires of Article 6 .

\section{a. The Travaux Préparatoires of Article 6}

The travaux preparatoires of Article 6 throw some light on the proper characterisation of the principle of equidistance as incorporated in Article 6. The relevant records are those relating to the debate that took place in the $1953 \mathrm{ILC}$ session, though, of course, the ILC had already considered the matter at some length in previous sessions.182 Prior to this session, the ILC Rapporteur, Professor François, had convened a Committee of Experts to advise on technical questions raised by delimitation of (primarily) the territorial sea. In its report, 183 the Committee of Experts added a comment to the effect that, in relation to questions VI and VII (international boundaries between opposite and adjacent coasts respectively), the Committee had considered it important to find a formula that could also be used for the delimitation of the respective continental shelves of two States bordering the same continental shelf.

For opposite coasts the Committee recommended "the median line, every point of which is equidistant from the baselines of the States concerned." It added that: "There may, however, be special reasons, such as navigation and fishing rights, which may divert the boundary from the median line."184

For adjacent coasts the Committee recommended that the lateral boundary, if not already fixed otherwise, should be drawn ac-

182. See E. BRown, supra note 60 , at 52-57.

183. Rapport du Comité d'experts sur certaines questions d'ordre technique concernant la mer territoriale, in Additif au deuxième rapport de M.J.P.A. François, rapporteur spécial app., U.N. Doc. A/CN.4/61/Add. 1 (1953), reprinted in [1953] 2 Y.B. INT'L L. COMM'N 75, 77, U.N. Doc. A/CN.4/SER.A/1953/Add. 1 (1959). The report is reproduced in English at Counter-Memorial of Denmark, 1 North Sea Continental Shelf Cases, I.C.J. Pleadings 157, 254 (1968).

184. Though the discussions of the Committee are not recorded, Professor François, who chaired its meetings, has confirmed that these latter considerations referred to the territorial sea and that navigation and fishing rights in the Continental Shelf were protected by Article 5 of the Commission's draft. Summary Records of the 204th Meeting, [1953] 1 Y.B. INT'L L. Comm'N 124, 127, U.N. Doc. A/CN.4/SER.A/1953 (1959). See Geneva Convention, supra note 4, art. 5. 
cording to the principle of equidistance from the respective coastlines. It added, however, that: "In a number of cases this may not lead to an equitable solution, which should then be arrived at by negotiation." 185

In the light of this report, Professor François presented a new draft Article 7.186 For opposite coasts he proposed that the boundary should be "the median line every point of which is equidistant from the two opposite coasts"; and, for adjacent States, the boundary was to be drawn "according to the principle of equidistance."187 In neither case was any reference made to either agreement or special circumstances. The draft did, however, provide for arbitration if parties could not agree on how the lines were to be drawn in accordance with this principle. It was on the basis of this draft that the Commission's crucial debate took place during the 1953 session. Because the formula that emerged from that debate is in its essentials that of the present Article 6 of the Geneva Convention, it is useful to refer in some detail to a few of the key contributions to the debate.

The element of agreement was re-introduced by Professor Pal, who proposed the addition of the words "unless otherwise amicably determined by them."188 Similarly, the element of exceptional situations was re-introduced by Professor Sandström, and the Rapporteur agreed that there were cases when a departure from the general rule was necessary-for example, when a small island near one State's coast belonged to another State.189 Admitting, therefore, that, although a general rule was necessary, it was also necessary to provide exceptions to it, the Rapporteur suggested a further formulation referring to agreement or to the median line "as a general rule."190

Professor Lauterpacht objected, however, that it was arguable that the words "as a general rule" would deprive the rule of its

185. Summary Records of the 204th Meeting, [1953] 1 Y.B. INT'L L. COMM'N 124, 127, U.N. Doc. A/CN.4/SER.A/1953 (1959).

186. Summary Records of the 201st Meeting, [1953] 1 Y.B. INT'L L. CoMm'N 103, 106, U.N. Doc. A/CN.4/SER.A/1953 (1959).

187. Id.

188. Summary Records of the 204th Meeting, [1953] 1 Y.B. INT'L L. COMM'N 124, 125, U.N. Doc. A/CN.4/SER.A/1953 (1959).

189. Id, at 128, para. 37. An excellent example is provided by the boundary between Colombia and Venezuela in the Gulf of Venezuela. See Boggs, Delimitation of Seaward Areas Under National Jurisdiction, 45 AM. J. INT'L L. 240, 261-63 (1951).

190. Summary Records of the 204th Meeting, [1953] 1 Y.B. INT'L L. CoMm'N 124, 128, U.N. Doc. A/CN.4/SER.A/1953 (1959). 
legal character. He suggested that the commentary on the draft article might contain a full explanation, giving specific instances of cases in which a departure from the rule was permissible.191 $\mathrm{He}$ also was unhappy with the formula proposed by Professor Spiropoulos: "unless another boundary line is justified by special circumstances."192 "If the Commission had certain specific exceptions in mind, [Professor Lauterpacht felt that] it should say so. But to state generally that arbitrators should take exceptions into consideration was tantamount to giving them the power to judge ex aequo et bono, which the Commission did not intend to do."193 However, Professor Spiropoulos persisted with his amendment, revised to read: "unless special circumstances justify another delimitation."194

In a final effort to achieve greater precision, Professor Lauterpacht proposed the following formula: "In cases in which such delimitation is physically impossible or in which it may cause undue hardship to one of the coastal States, the line shall be determined by arbitration in a manner approximating as closely as possible to the principle of equidistance."195 Subsequently, however, Professor Lauterpacht withdrew this amendment "provided an explicit reference were included in the comments to the extent of the latitude to be given to arbitrators."196

As adopted by the ILC in 1953,197 Article 7 thus included reference to three elements: (1) agreement, (2) the principle of equidistance, and (3) "unless another boundary line is justified by special circumstances."198

191. Id. para. 47 , at $129-30$, para. 61 .

192. Id. at 130 , para. 62 .

193. Summary Records of the 205th Meeting, [1953] 1 Y.B. INT'L L. Comm'N 130, 131, para. 17, U.N. Doc. A/CN.4/SER.A/1953 (1959).

194. Id. at 132, para. 29. He argued that, because the Commission had accepted the principle of arbitration, it must be left to the arbitrators to assess the special circumstances. Elsewhere, he said that his proposal would enable arbitrators to settle disputes ex aequo et bono. For instance, in cases in which an island belonged to one State but was situated in the territorial waters of another, arbitrators would have to judge ex aequo et bono. Id. para. 21. He considered that: "His formula made it perfectly clear that only in cases where the application of the rule would lead to manifest unfairness would it have to be waived." Id. at 133, para. 39.

195. Id. at 132, para. 23 (emphasis added).

196. Id. at 133, para. 34 .

197. Report of the International Law Commission to the General Assembly, 8 U.N. GAOR, Supp. (No. 9) 13, art. 7, U.N. Doc. A/2456 (1953), reprinted in [1953] 2 Y.B. INT'L L. COMM'N 200, 213, U.N. Doc. A/CN.4/SER.A/1953/Add. 1 (1959). 198. Id. Article 7 read:

1. Where the same continental shelf is contiguous to the territories of two or more States whose coasts are opposite to each other, the boundary of the continental shelf appertaining to such States is, in the absence of agreement between those States or unless another boundary line is justified by special circumstances, the median line every point of which is 
In the ILC's comments on the draft articles, it was stated that:

Moreover, while in the case of both kinds of boundaries [between opposite States and between adjacent States] the rule of equidistance is the general rule, it is subject to modification in cases in which another boundary line is justified by special circumstances. As in the case of the boundaries of coastal waters, provision must be made for departures necessitated by any exceptional configuration of the coast, as well as the presence of islands or of navigable channels. To that extent the rule adopted partakes of some elasticity. In view of the general arbitration clause of article $8 \ldots$ no special provision was considered necessary for submitting any resulting disputes to arbitration. Such arbitration, while expected to take into account the special circumstances calling for modification of the major principle of equidistance, is not contemplated as arbitration ex aequo et bono. That major principle must constitute the basis of arbitration, conceived as settlement on the basis of law, subject to reasonable modifications necessitated by the special circumstances of the case. 199

Article 8 provided: "Any disputes which may arise between States concerning the interpretation or application of these articles should be submitted to arbitration at the request of any of the parties." 200

The substance of Article 7, as adopted in 1953, was incorporated in the reformulated Article 72 in the final report of the ILC in 1956.201 As, however, the reference to arbitration in Article 8 of

equidistant from the base lines from which the width of the territorial sea of each country is measured.

2. Where the same continental shelf is contiguous to the territories of two adjacent States, the boundary of the continental shelf appertaining to such States is, in the absence of agreement between those States or unless another boundary line is justified by special circumstances, determined by application of the principle of equidistance from the base lines from which the width of the territorial sea of each of the two countries is measured.

199. Id. at 16, reprinted in [1953] 2 Y.B. INT'L L. COMM'N at 216.

200. Id. at 13, reprinted in [1953] 2 Y.B. INT'L L. COMM'N at 213.

201. The text of Article 7 (1953) is in note 198 supra. Article 72 (1956) read:

1. Where the same continental shelf is adjacent to the territories of two or more States whose coasts are opposite to each other, the boundary of the continental shelf appertaining to such States shall be determined by agreement between them. In the absence of agreement, and unless another boundary line is justified by special circumstances, the boundary is the median line, every point of which is equidistant from the baselines from which the breadth of the territorial sea of each country is measured.

2. Where the same continental shelf is adjacent to the territories of two adjacent States, the boundary of the continental shelf shall be determined by agreement between them. In the absence of agreement, and unless another boundary line is justified by special circumstances, the boundary shall be determined by application of the principle of equidistance from the baselines from which the breadth of the territorial sea of each of the two countries is measured.

Report of the International Law Commission to the General Assembly, 11 U.N. 
the 1953 draft was replaced by reference to the I.C.J. in Article 73 of the 1956 draft,202 the commentary to Article 72 differed from its 1953 equivalent. Paragraph (1) read as follows:

For the determination of the limits of the continental shelf the Commission adopted the same principles as for the articles 12 and 14 concerning the delimitation of the territorial sea. As in the case of the boundaries of the territorial sea, provision must be made for departures necessitated by any exceptional configuration of the coast, as well as the presence of islands or of navigable channels. This case may arise fairly often, so that the rule adopted is fairly elastic. 203

While it is true that this relatively shorter commentary omits the emphasis in the 1953 report on the "major principle of equidistance" as constituting the basis of a legal settlement, nothing in the 1956 debates suggests that the omission reflected a change in the Commission's position. It seems rather that it disappeared together with the general reference to arbitration.

The 1958 Geneva Conference revised the ILC's draft Article 72 only to a very minor extent. The changes incorporated in what then became Article 6 of the Geneva Convention are irrelevant in the present context.

Reviewing this record, it would seem fair to say that:

1. The Committee of Experts regarded the principle of equidistance as the general rule, while noting that it would have to admit of exceptions where there were "special reasons" or where its application would "not lead to an equitable solution."

2. The International Law Commission, in its crucial 1953 session, conducted its debate on the assumption that the principle of equidistance was "the general rule" and referred to it also as "the major principle of equidistance." "Modifications necessitated by the special circumstances of the case" were very clearly regarded as exceptions to the major principle.

3. Although the shorter commentary in the ILC 1956 report omits reference to "the major principle of equidistance" and does note that the case for a departure from the equidistance principle "may arise fairly often," nothing in the record of the ILC debate suggests that the ILC had ceased to regard the equidistance principle as "the general rule" or "the major principle."

4. The 1958 Geneva Conference, having made no relevant change to the ILC's draft Article, may be taken to have endorsed the Commission's view as to the status of the equidistance principle.

GAOR, Supp. (No. 9) 44, U.N. Doc. A/3159 (1956), reprinted in [1956] 2 Y.B. INr'L L. COMM'N 253, 300, U.N. Doc. A/CN.4/SER.A/1956/Add. 1 (1957).

202. Id.

203. Id. art. 72 commentary (1). 
The conclusion must be, therefore, that the travaux preparatoires provide strong evidence that the intention of the parties to the Geneva Convention was that the equidistance principle of Article 6 should be regarded as "the general rule" or "the major principle" and that the special circumstances rule was regarded as being an exception to the general rule.

It is submitted that the classification of the equidistance principle as "the general rule" or "the major principle" means that there is a presumption in favour of the rule; that it is the residual rule; that the onus lies on those pleading exceptions to it to prove the presence of special circumstances. Nor need this conclusion be disturbed if, following the Court of Arbitration, one regards Article 6 as having formulated a combined equidistance-special circumstances rule rather than two separate rules.

\section{b. The Decision of the Court of Arbitration}

The Court of Arbitration adopted a different view of the status of the principle of equidistance. The United Kingdom had argued that Article 6(1) placed an onus of proof upon France to show the existence of any special circumstances on which it relied and to show that these circumstances justified a boundary other than the median line as defined by that paragraph.204 The Court of Arbitration considered, however, that this view did not place the equidistance principle in its true perspective and went on as follows:

Article 6, as both the United Kingdom and the French Republic stress in the pleadings, does not formulate the equidistance principle and "special circumstances" as two separate rules. The rule there stated in each of the two cases is a single one, a combined equidistance-special circumstances rule. This being so, it may be doubted whether, strictly speaking, there is any legal burden of proof in regard to the existence of special circumstances. The fact that the rule is a single rule means that the question whether "another boundary is justified by special circumstances" is an integral part of the rule providing for application of the equidistance principle. As such, although involving matters of fact, that question is always one of law of which, in case of submission to arbitration, the tribunal must itself, proprio motu, take cognisance when applying Article 6.205

For the reasons stated above, the Court of Arbitration's view on the legal burden of proof does not seem to be in accordance with the intention of the parties to the Geneva Convention; nor does the court appear to be certain of its own view. It says only that "it

204. Decision, supra note 7, para. 67 .

205. Id. para. 68 . 
may be doubted whether, strictly speaking, there is any legal burden of proof.'206

Professor Briggs also refers briefly to this point in the declaration that he appended to the decision of the Court of Arbitration. Professor Briggs stated that:

The view that Article 6 is expressive of customary international law-a view already held by some Judges of the International Court of Justice in 1969 in the North Sea Continental Shelf cases-has been substantially strengthened by the subsequent practice of States, which has been elaborately analyzed by counsel in this Arbitration. 207

Professor Briggs agreed with the court that whether it applied the principles of international customary law or those set forth in Article 6 of the Convention would make little practical difference "in the circumstances of this case." $208 \mathrm{He}$ went on to say, however, that:

My principal concern in this respect is that the Court's interpretation of Article 6 seems, in effect, to shift "the burden of proof" of "special circumstances" from the State which invokes them to the Court itself, and constitutes some threat that the rule of positive law expressed in Article 6 will be eroded by its identification with subjective equitable principles, permitting attempts by the Court to redress the inequities of geography. 209

That the writer shares this opinion will be evident from the following excerpt from a critical review, published in 1971, of the I.C.J.'s judgment in the North Sea Continental Shelf Cases:

In the writer's view, the record surveyed above amply verifies that in the course of a development over nearly a quarter of a century, the rules expressed in Article 6(2) of the Geneva Convention on the Continental Shelf have attained the status of international customary law. Two points must be emphasised. First, in view of the fact that both the German pleadings and the Court's Judgment concentrated on the question whether the evidence sufficed to prove the equidistance rule, it is necessary to emphasise that Article 6(2) contains three elements-agreement, equidistance and special circumstances. It is submitted that the latter two elements have now been accepted in State practice as being the rules the application of which will ensure that, failing agreement between the parties, a delimitation will be carried out in accordance with the "equitable principles" referred to in the Truman Proclamation.

Secondly, the assertion is not that State practice since 1958 (or 1964, when the Convention entered into force) has transformed the conventional rules into rules of international customary law but rather that, as a result of a process of refinement and consolidation of which the conclusion of the Convention was a part, the fundamental but vague notions of agreement and equity expressed in the Truman Proclamation were transformed into at least relatively more precise rules.

Prima facie, the difference between this conclusion and the Court's Judgment may seem slight. It is submitted, however, that the concept of special circumstances is much more limited in scope and less open to arbitrary concretisation than the general principle of equity as interpreted

206. Id.

207. Id. at 236.

208. Id. (emphasis added).

209. Id. 
by the Court.210

That the Court of Arbitration was aware of the greater latitude it would enjoy as a result of equating the rules of Article 6 with those of international customary law is clear from its observation that:

Clearly, this feature of Article 6 [the right to claim the existence of special circumstances whether or not a reservation with regard to such special circumstances had been made on ratification of the Convention] further underlines the full liberty of the Court in appreciating the geographical and other circumstances relevant to the determination of the continental shelf boundary, and at the same time reduces the possibility of any difference in the appreciation of these circumstances under Article 6 and customary law.211

\section{No Legal Limit to Considerations Which May Be Taken into Account to Ensure the Application of Equitable Principles}

As was noted above, the I.C.J. said in its judgment in the North Sea Cases that: "[T]here is no legal limit to the considerations which States may take account of for the purpose of making sure that they apply equitable procedures . . .."212 Clearly, if this passage is read in isolation and understood literally, it might be taken as authority for the invocation of a limitless variety of considerations as constituting factors productive of inequity. It is, therefore, fortunate that the Court of Arbitration had an opportunity in the Anglo-French Case to interpret this ambiguous and somewhat misleading passage.

Having decided that the position of the Scilly Isles constituted a "special circumstance" justifying a boundary other than the strict median line, the court went on to say that:

It does not, however, consider that the existence of this "special circumstance" in the Atlantic region gives it carte blanche to employ any method that it chooses in order to effect an equitable delimitation of the continental shelf. The French Republic, it is true, has impressed upon this Court certain observations in the Judgment in the North Sea Continental Shelf cases to the effect that, in order to achieve an equitable solution, "it is necessary to seek, not one method of delimitation but one goal" (paragraph 92), and that "there is no legal limit to the considerations which States may take account of for the purpose of making sure that they apply equitable procedures" (paragraph 93). But in those cases the Parties had retained the actual delimitation of the boundary in their own hands for further negotiation in the light of the principles and rules to be stated by

210. E. BRown, supra note 60 , at $61-62$ (emphasis original).

211. Decision, supra note 7 , para. 69 .

212. [1969] I.C.J. 3, para. 93. See text accompanying note 102 supra. 
the International Court of Justice; and in any event the observations invoked by the French Republic have to be read in the light of certain other observations of the International Court in the same Judgment. In these other observations, it was stressed that any recourse to equitable considerations must be to considerations "lying not outside but within the rules" of law, and that there is no question of any decision ex aequo et bono (paragraph 88); and, as already noted, it was also stressed that "there can never be any question of completely refashioning nature" (paragraph 91). 213

\section{The Proportionality Factor}

As has been seen, the I.C.J. held, in its judgment in the North Sea Cases, that to ensure the application of equitable principles to the delimitation of the continental shelf, account had to be taken of

the element of a reasonable degree of proportionality which a delimitation effected according to equidistance principles ought to bring about between the extent of the continental shelf appertaining to the States concerned and the length of their respective coastlines-these being measured according to their general direction in order to establish the necessary balance between States with straight and those with markedly concave or convex coasts or to reduce very irregular coastlines to their truer proportions. 214

Earlier in the judgment, the court held that "given a geographical situation of quasi-equality-in the length of the coastal frontages of the three States-one must abate the effects of an incidental special feature from which an unjustifiable difference of treatment could result."215 In an earlier work, the writer suggested that this proposition seemed to rest on three assumptions, all of which were questionable:

First, the Court isolates one factor-length of coast-and uses this as the criterion of equitable apportionment. Why not use population, per capita income, land area, dependence of industry on the natural resources of the shelf, relative poverty of land resources? Secondly, the shape of the German coast is described as "an incidental special feature," though one might well think that the characteristic shape of the whole of the German North Sea coast is less incidental than the ratio between the lengths of the coasts of the three States. Thirdly, strict application of the equidistance principle would, it is said, cause an "unjustifiable difference in treatment." But, of course, the treatment would only be unjustifiable in terms of the results to be expected from application of the quasi-equality doctrine, which would demand reasonable proportionality between coastal frontage and area of shelf-another assumption.

It will be noted, furthermore, that adoption of the quasi-equality/proportionality test involves acceptance of the so-called macrogeographical perspective advocated by German Counsel. The calculation of reasonable proportionality of the continental shelves of States A and B by reference to coastal frontage, may-and in this case does-require a consideration of the shelf of State C, for it is only by reference to State B's boundary with State C that the area of State B's continental shelf may be

213. Decision, supra note 7, para. 245.

214. [1969] I.C.J. 3, para. 98.

215. Id. paras. 89-91. 
calculated. But, what justification is there for asserting the relevance of the boundary between States $B$ and $C$ to delimitation of the boundary between $A$ and $B$ ? The Court certainly provides none other than its ex cathedra deduction from equitable principles. In a case before the Court between $A$ and $B$, is State $C$ to be bound by the frontier between it and $B$ which the Court uses as a basis for application of the proportionality rule?216

Fortunately, the Court of Arbitration has now reconsidered the significance of the proportionality factor and has placed it in its proper perspective. Having recognised that the concept of proportionality was "clearly inherent in the notion of a delimitation in accordance with equitable principles" and that it thus formed "an element in the appreciation of the appropriateness of the equidistance or any other method of delimitation,"217 the court went on to deny that this concept had the character of a specific principle or rule of delimitation as had been contended by France. It continued:

In particular, this Court does not consider that the adoption in the North Sea Continental Shelf cases of the criterion of a reasonable degree of proportionality between the areas of continental shelf and the lengths of the coastlines means that this criterion is one for application in all cases. On the contrary, it was the particular geographical situation of three adjoining States situated on a concave coast which gave relevance to that criterion in those cases. In the present case, the role of proportionality in the delimitation of the continental shelf is, in the view of this Court, a broader one, not linked to any specific geographical feature. It is rather a factor to be taken into account in appreciating the effects of geographical features on the equitable or inequitable character of a delimitation, and in particular of a delimitation by application of the equidistance method.218

The role of the proportionality factor was further specified in this passage:

[P] articular configurations of the coast or individual geographical features may, under certain conditions, distort the course of the boundary, and thus affect the attribution of continental shelf to each State, which would otherwise be indicated by the general configuration of their coasts. The concept of "proportionality" merely expresses the criterion or factor by which it may be determined whether such a distortion results in an inequitable delimitation of the continental shelf as between the coastal States concerned. The factor of proportionality may appear in the form of the ratio between the areas of continental shelf to [sic] the lengths of the respective coastlines, as in the North Sea Continental Shelf cases. But it may also appear, and more usually does, as a factor for determining the reasonable or unreasonable-the equitable or inequitable-effects of particular geographical features or configurations upon the course of an equidistance-line boundary. 219

216. E. Brown, supra note 60 , at 50 .

217. Decision, supra note 7, para. 98 .

218. Id. para. 99.

219. Id. para. 100. 
In short, it is disproportion rather than any general principle of proportionality which is the relevant criterion or factor ... . Proportionality, therefore is to be used as a criterion or factor relevant in evaluating the equities of certain geographical situations, not as a general principle providing an independent source of rights to areas of continental shelf.220

A practical example of the application of the proportionality factor is furmished by the Court of Arbitration's treatment of the Scilly Isles. In relation to these islands, the court explained that:

"[P]roportionality" comes into account only in appreciating whether the Scilly Isles are to be considered a "special circumstance" having distorting effects on the equidistance boundary as between the French Republic and the United Kingdom and, if so, the extent of the adjustment appropriate to abate the inequity. These questions do not therefore require nice calculations of the areas of continental shelf appertaining to the United Kingdom in the north under a prospective delimitation of its continental shelf boundary with the Irish Republic. The point here at issue is simply whether the geographical situation of the Scilly Isles in relation to the French coast has a distorting effect and is a cause of inequity as between the United Kingdom and the French Republic.221

There was thus no question of elaborate calculations of length of coasts and areas of shelf or of choosing between macrogeographical and microgeographical perspectives.222 Instead, the court, having regard to the fact that the Scillies extended the United Kingdom coastline into the Atlantic twice as far as Ushant extended the French coastline, decided that application of the "halfeffect" method ${ }^{223}$ would serve to achieve the necessary abatement of the inequity so caused.224

It seems right to conclude that what has survived the court's reconsideration of the "proportionality factor" is simply the unexceptionable proposition that the broad notion of proportionality is one that may be called in aid to help in establishing whether a particular feature does constitute special circumstances because of its unjust distorting effects.

\section{Opposite-State and Adjacent-State Situations Distinguished}

Unlike Article 12 of the Geneva Convention on the Territorial Sea,225 Article 6 of the Geneva Convention on the Continental Shelf deals with opposite-State and adjacent-State situations in separate paragraphs. To the I.C.J., the reason for this was plain. In an opposite-State situation, "ignoring the presence of islets, rocks and minor coastal projections, the disproportionally dis-

220. Id. para. 101.

221. Id. para. 250.

222. Id. para. 166.

223. See id. para. 251 (explanation).

224. Id.

225. Convention on the Territorial Sea and the Contiguous Zone, done Apr. 29, 1958, art. 12, [1964] 15 U.S.T. 1606, T.I.A.S. No. 5639, 516 U.N.T.S. 205. 
torting effect of which can be eliminated by other means,"226 a median line "must effect an equal division of" 227 the shelf areas concerned. In the case of "laterally adjacent States on the same coast with no immediately opposite coast in front of it,"228 however,

in certain geographical circumstances ... the equidistance method ... leads unquestionably to inequity . . . :

(a) ... Thus it has been seen that in the case of concave or convex coastlines that if the equidistance method is employed, then the greater the irregularity and the further from the coastline the area to be delimited, the more unreasonable are the results produced. ${ }^{229}$

Obviously, such distortions are comparatively small within the narrow limits of the territorial sea230-hence the difference between the delimitational rules in the two Conventions.

The I.C.J.'s somewhat rigid differentiation between the two types of situations was again apparent in its finding-admittedly obiter-that Article 6 could not apply to a delimitation between Denmark and the Netherlands because they were neither "adjacent" nor "opposite" to one another.231 The Court of Arbitration, in its review of this question, has adopted a much broader approach to the interpretation of Article 6, which seems to this writer to be much more in accordance with the intention of the parties to the Geneva Convention.

The court divided the "arbitration area" into an "English Channel region" and an "Atlantic region." In relation to the English Channel region, the court agreed with the view of the parties that it had to deal with an opposite-States situation and that the appropriate method of delimitation was, in principle, that of equidistance.232 With regard to the Atlantic region, the parties were not at all in agreement. France argued that because the United Kingdom and France are separated by the Channel, the Atlantic region could not be considered to be an adjacent-States situation; and that because the Atlantic region lies off the two coasts rather than between them, it was not an opposite-States situation. It concluded that it was a situation sui generis and a casus omissus

226. North Sea Continental Shelf Cases, [1969] I.C.J. 3, para. 57.

227. Id.

228. Id.

229. Id. para. 89.

230. Id. para. 59.

231. Id. para. 36.

232. Decision, supra note 7 , para. 87 . 
falling completely outside Article 6 of the Geneva Convention.233 The United Kingdom, on the other hand, contended that Article 6 was intended to deal comprehensively with the delimitation of the continental shelf and that there could be no question of casus omissus. Moreover, even though the Atlantic region lay off the coasts of the two countries, it was still essentially an oppositeStates situation. 234

The court endorsed the United Kingdom view that Article 6 was to be regarded as comprehensive and that all situations must, therefore, in principle, fall under either paragraph 1 or paragraph 2 of that Article.235 It next interpreted the passage in the judgment in the North Sea Continental Shelf Cases, where the I.C.J. had noted that: "In certain geographical configurations of which the Parties furnished examples, a given equidistance line may partake in varying degree of the nature both of a median and of a lateral line."236 What this meant, the Court of Arbitration held, was that

in determining whether two States are to be considered as "opposite" or "adjacent," for the purpose of delimiting a continental shelf on which each of them abuts, the Court must have regard to their actual geographical relation to each other and to the continental shelf at any given place along the boundary. 237

The Court of Arbitration cited two further passages from the judgment in the North Sea Cases, where, as was noted above, the I.C.J. had said that:

[W] hereas a median line divides equally between the two opposite countries areas that can be regarded as being the natural prolongation of the territory of each of them, a lateral equidistance line often leaves to one of the States concerned areas that are a natural prolongation of the territory of the other; ${ }^{238}$

and had pointed out that

if the equidistance method is employed, then the greater the irregularity and the further from the coastline the area to be delimited, the more unreasonable are the results produced. So great an exaggeration of the consequences of a natural geographical feature must be remedied or compensated for as far as possible, being of itself creative of inequity. ${ }^{239}$

Commenting on these passages, the Court of Arbitration said that:

It is also clear that the distinction drawn by the Court between the two geographical situations is one derived not from any legal theory but from the very substance of the difference between the two situations. Whereas in the case of "opposite" States a median line will normally effect a

233. Id. paras. $89-90$.

234. Id. paras. 91-93.

235. Id. para. 94.

236. [1969] I.C.J. 3, para. 6.

237. Decision, supra note 7, para. 94 .

238. [1969] I.C.J. 3, para. 58.

239. Id. para. $89(a)$. 
broadly equitable delimitation, a lateral equidistance line extending outward from the coasts of adjacent States for long distances may not infrequently result in an inequitable delimitation by reason of the distorting effect of individual geographical features. In short, it is the combined effect of the side-by-side relationship of the two States and the prolongation of the lateral boundary for great distances to seawards which may be productive of inequity and is the essence of the distinction between "adjacent" and "opposite" coasts situations. 240

Reverting to this point in a later passage, the Court of Arbitration was of the view that "the precise system of toponomy adopted for these various areas is without any legal relevance in the present proceedings; it is the physical facts of geography, not nomenclature, with which this Court is concerned."241

\section{The court developed this thinking at greater length:}

As this Court of Arbitration has already pointed out in paragraphs 81-94, the appropriateness of the equidistance or any other method for the purpose of effecting an equitable delimitation in any given case is always a function or reflection of the geographical and other relevant circumstances of the particular case. In a situation where the coasts of the two States are opposite each other, the median line will normally effect a broadly equal and equitable delimitation. But this is simply because of the geometrical effects of applying the equidistance principle to an area of continental shelf which, in fact, lies between coasts that, in fact, face each other across that continental shelf. In short, the equitable character of the delimitation results not from the legal designation of the situation as one of "opposite" States but from its actual geographical character as such. Similarly, in the case of "adjacent" States, it is the lateral geographical relation of the two coasts when combined with a large extension of the continental shelf seawards from those coasts, which makes individual geographical features on either coast more prone to render the geometrical effects of applying the equidistance principle inequitable than in the case of "opposite" States. The greater risk in these cases that the equidistance method may produce an inequitable delimitation thus also results not from the legal designation of the situation as one of "adjacent" States but from its actual geographical character as one involving laterally related coasts.

What is, moreover, evident is that the relevance of the distinction between opposite and adjacent coasts is in regard to the operation of the "special circumstances" element in the "equidistance-special circumstances" rule laid down in Article 6 for both situations. What is also evident in the view of the Court, is that the answer to the question whether the effect of individual geographical features is to render an equidistance delimitation "unjustified" or "inequitable" cannot depend on whether the case is legally to be considered a delimitation between "opposite" or between "adjacent" States. The appreciation of the effect of individual geographical features on the course of an equidistance line has necessarily to be made by reference to the actual geographical conditions of the particular area of continental shelf to be delimited and to the actual relation of the two coasts to

240. Decision, supra note 7, para. 95 .

241. Id. para. 204. 
that particular area.242

The court was "inclined to the opinion"243 that the Atlantic region was an opposite-States situation rather than an adjacentStates situation. More important, however, was its view that:

[T] f fix the precise legal classification of the Atlantic region appears to this Court to be of little importance. The rules of delimitation prescribed in paragraph 1 and paragraph 2 are the same, and it is the actual geographical relation of the coasts of the two States which determine their application. What is important is that, in appreciating the appropriateness of the equidistance method as a means of effecting a "just" or "equitable" delimitation in the Atlantic region, the Court must have regard both to the lateral relation of the two coasts as they abut upon the continental shelf of the region and to the great distance seawards that this shelf extends from those coasts. 244

This eminently sensible and practicable interpretation of Article 6 will be of considerable assistance to States in negotiating continental shelf boundaries with neighbouring States where nature has been untidy enough to present a configuration that is not obviously either an opposite-States or an adjacent-States situation.

6. Islands and Archipelagos

The Court of Arbitration had to consider whether the following features constituted special circumstances or factors creative of inequity: (1) the Channel Islands, and (2) Ushant and the Scilly Isles.

\section{a. The Channel Islands}

The court's treatment of the Channel Islands 245 in relation to the delimitation of the continental shelf is of considerable interest, being the first time that an international tribunal has had to consider the significance for delimitational purposes of an archipelago situated close to the mainland of one State but under the sovereignty of a neighbouring State. The Greek and Turkish governments will certainly wish to scrutinise the decision closely for its possible bearing upon the delimitation of the continental shelf in the Aegean, where the Turkish coast is fringed by a number of substantial Greek islands.

As was seen above, the court held that Article 6 of the Geneva Convention is not applicable in this area and that this part of the boundary has to be constructed in accordance with international

242. Id. paras. $239-40$.

243. Id. para. 242.

244. Id.

245. For a description of the geography of this archipelago, the submarine geology of the area, and the constitutional status of the Channel Islands, see Decision, supra note 7, paras. 6-9. 
customary law.246 The significance of this finding was reduced almost to nil, however, when the court reached the conclusion that "the different ways in which the requirements of 'equitable principles' or the effects of 'special circumstances' are put reflect differences of approach and terminology rather than of substance."247 The court went on to say that:

[T] he substantial point at issue is whether the presence of the British archipelago of the Channel Islands close to the French coast is a "special circumstance" or a circumstance creative of inequity that calls for a departure from or variation of the equidistance method of delimitation which the Parties agree to be in principle the applicable method. ${ }^{248}$

It would seem, therefore, that the court would have reached the same result by way of the same arguments even had it found Article 6 directly applicable.

The somewhat circuitous route by which the court arrived at the conclusion that the Channel Islands do constitute special circumstances has been reviewed above in part IV in relation to the concept of natural prolongation.249 The object of this section is to examine the court's finding only as it bears upon the question of what S.W. Boggs called islands "on the wrong side of the median line." 250

France had argued before the court that the opposite coasts to be taken into account were those of the two mainlands and that the boundary should consist of (1) a median line between the mainlands, and (2) a six-mile line around the islands, creating a Channel Islands enclave. ${ }^{251}$

The United Kingdom, on the other hand, would have had the court treat the Channel Islands as the coast of the United Kingdom opposite to France in that part of the Channel. Accordingly, the median line should describe a deep loop south round the Channel Islands, close to the French coast.252

As has been seen, the court decided to draw two boundary lines, the first being a median line drawn by reference to the two mainlands and the second, a twelve-mile line to the north and west of the Channel Island archipelago. This finding seems to be

246. See text accompanying notes $23 \& 42$ supra.

247. Decision, supra note 7, para. 148.

248. Id.

249. Pt. IV(B) supra.

250. Quoted in Decision, supra note 7, para. 159.

251. Id. paras. 146-50.

252. Id. para. 154 . 
rather extraordinary. As it will doubtless be much cited in the future, the reasoning behind it deserves close scrutiny.

The main steps in the court's argument are as follows:

1. The region forms an integral part of the English Channel and must be viewed in its context as part of that whole maritime area.253

Along the whole 300 miles of the south coast of the Channel runs the mainland coast of the French Republic; along the whole 300 miles of the north coast of the Channel runs the mainland coast of the United Kingdom. Each country has some promontories on its coast and the general result is that the coastlines of their mainlands face each other across the Channel in a relation of approximate equality. 254

2. Having thus established the macrogeographical perspective in which to consider the Channel Islands region, the court went on to observe that:

[W] here the coastlines of two opposite States are themselves approximately equal in their relation to the continental shelf not only should the boundary in normal circumstances be the median line but the areas of shelf left to each Party on either side of the median line should be broadly equal or at least broadly comparable. ${ }^{255}$

Acknowledging that the presence of the Channel Islands disturbed "the balance of the geographical circumstances,"256 the court felt that the question to be decided was whether, and if so, in what manner this disturbance should affect the "legal framework"257 within which the boundary had to be delimited.

3. The court found that the legal framework was "that of two opposite States one of which possesses island territories close to the coast of the other State."258 It added that the size and importance of the Channel Islands might properly be taken into account in balancing the equities in the region. 259

Also part of this legal framework were the twelve-mile fishery limits of France and of the United Kingdom, the twelve-mile territorial sea of France, and the three-mile and the potential twelvemile territorial sea limits of the United Kingdom. 260

Finally, "other elements in the framework"261 were the various equitable considerations invoked by the parties regarding their navigational, defence, and security interests. The court found that in the circumstances of the case these considerations carried

253. Id. para. 181.

254. Id.

255. Id. para. 182.

256. Id. para. 183.

257. Id.

258. Id. para. 187.

259. Id.

260. Id.

261. Id. para. 188. 
little weight and might simply "support and strengthen, but [could not] negative, any conclusions that are already indicated by the geographical, political and legal circumstances of the region which the Court has identified."262 In the court's view they tended to evidence the predominant interests of the French Republic in the southern areas of the English Channel.

4. Following its consideration of the natural prolongation doctrine, the court went on to hold that: "Any ground of equity . . . is ... to be looked for in the particular circumstances of the present case and in the particular equality of the two States in their geographical relation to the continental shelf of the Channel."263

The court found that to give full effect to the Islands would result in a substantial diminution of the area of the shelf that would otherwise accrue to France; that this fact was prima facie creative of inequity; and that the presence of the islands would, prima facie, constitute a "special circumstance" if Article 6 were applicable. Prima facie, therefore, a departure from the median line seemed to be justified. It was necessary to show, however, that a departure from the median line would be "equitable" or "justified" also in relation to the United Kingdom and in the light of all the relevant circumstances. 264

The court accepted that a certain weight should be attached to the equitable considerations invoked by the United Kingdom-the political and economic character of the Islands, their close ties with the United Kingdom and the latter's responsibility for their defence and security, and the fact that they had the possibility of enjoying an appreciable area of continental shelf only to their west and north. 265

5. Weighing the various equities in the balance, the court decided that the primary element was that the Channel Islands region forms part of the English Channel, throughout the whole length of which the parties face each other as opposite States having almost equal coastlines.266 In the court's view the equitable considerations invoked by the United Kingdom invalidated the French proposal for a six-mile enclave for the Channel Islands but did not justify the adoption of the United Kingdom's propos-

262. Id.

263. Id. para. 195.

264. Id. para. 197.

265. Id. para. 198

266. Id. para. 199. 
als.267 As has been seen, the court drew two lines, a median line between the two mainlands and a second twelve-mile line to the north and west of the Islands.

Whether viewed as the application of international customary law or as indicative of what the court's findings would have been had Article 6 been directly applicable, the court's ruling in this region seems hard to justify. No one, probably, would quarrel with the court's finding that the presence of the Islands constitutes special circumstances or a factor creative of inequity. However, it is difficult to regard the remedy prescribed by the court as other than the substitution of one inequity for another. Having rejected the line claimed by the United Kingdom (a deep loop south round the Islands), it was open to the court to balance the equities and to give effect to the equitable considerations invoked by the United Kingdom in any one of at least three ways. First, it could have denied the United Kingdom any continental shelf around the Islands but compensated it with a southward bulge in the mid-Channel median line. Second, it could have sanctioned both a continental shelf enclave around the Islands and a more limited southward bulge in the median line. The court preferred the third option-the retention of an unmodified mid-Channel median line and the establishment of an enclave around the Islands. Although the "potentiality of an extension" of the United Kingdom territorial sea to twelve miles was one of the elements taken into account by the Court in determining the dimensions of this enclave, 268 it nevertheless purported to achieve an equitable result by limiting the breadth of the enclave to twelve miles. Considering that the United Kingdom could have secured territorial sea rights in the whole of this enclave simply by extending its territorial sea to the twelve-mile breadth enjoyed by France since 1971, such an outcome can scarcely be described as equitable. Indeed, such a delimitation seems almost to deny that islands are entitled to a continental shelf, though of course such a denial would be difficult to square with Article 1 of the Geneva Convention on the Continental Shelf and its endorsement by the I.C.J. as declaratory of international customary law. ${ }^{269}$ The delimitation is all the more difficult to accept as a properly balanced judgment of the equities when one recalls that the Islands comprise a land area of 195 square kilometres and support a population of 130,000. The court's evaluation of the equities certainly seems less persuasive here than in relation to the Scilly Isles.

267. Id. para. 198.

268. Id. para. 187.

269. See North Sea Continental Shelf Cases, [1969] I.C.J. 3, para. 63. 


\section{b. The Scilly Isles}

The court's treatment of the Scilly Isles offers an instructive example of an archipelago 270 on the "right" side of the median line constituting special circumstances. As the court pointed out, the greater projection of the United Kingdom coast into the Atlantic region, though partly due to the fact that the United Kingdom mainland extends one degree further west than the French mainland, is also due to the greater extension westwards of the Scilly Isles beyond the United Kingdom mainland than that of Ushant beyond the French mainland.

Thus, at its nearest point, Ushant is only about 10 miles and at its most westerly point no more than 14.1 nautical miles from the coast of Finistere; the nearest point of the Scilly Isles, on the other hand, is some 21 nautical miles and their most westerly point some 31 miles distant from Land's End. As a result, even when account is taken of the slight southwesterly trend of the English Channel, the further extension south-westwards of the United Kingdom's coast has a tendency to make it obtrude upon the continental shelf situated to seawards of the more westerly facing coast of the French Republic in that region.271

As the court indicated in a later passage:

The effect of the presence of the Scilly Isles west-south-west of Cornwall is to deflect the equidistance line on a considerably more south-westerly course than would be the case if it were to be delimited from the baselines of the English mainland. The difference in the angle is $16^{\circ} 36^{\prime} 14^{\prime \prime}$; the extent of the additional area of shelf accruing to the United Kingdom, and correspondingly not accruing to the French Republic, in the Atlantic region eastwards of the one thousand metre isobath is approximately four thousand square miles. 272

The court did, of course, acknowledge that this fact of nature did not in itself justify a departure from an equidistance line drawn by reference to the Scillies. The question was rather to decide whether "in the light of all the pertinent geographical circumstances, that fact amounts to an inequitable distortion of the equidistance line producing disproportionate effects on the areas of shelf accruing to the two States." 273

The court decided that it did. In its view,

the further projection westwards of the Scilly Isles, when superadded to the greater projection of the Cornish mainland westwards beyond Finistere, is of much the same nature for present purposes, and has much the same tendency to distortion of the equidistance line, as the projection

270. The Scillies Group consists of 48 islands, six of which are inhabited, with a total population (in 1971) of 2,428 . Decision, supra note 7, para. 4 .

271. Id. para. 235.

272. Id. para. 243.

273. Id. 
of an exceptionally long promontory, which is generally recognized to be one of the potential forms of "special circumstances."274

As noted above, the court held that to give "half-effect" to the Scillies would bring about an appropriate abatement of the disproportionate effects of this "considerable projection onto the Atlantic continental shelf of a somewhat attenuated portion of the coast of the United Kingdom."275

274. Id. para. 244.

275. Id. para. 249. It is, however, seriously open to doubt whether an "appropriate abatement" was effected by the boundary line specified in the court's dispositif and drawn on the Boundary-Line Chart. In applying to the court for an interpretation of the Decision of June 30,1977, the United Kingdom argued that there was an inconsistency between the method of delimitation prescribed by the court in the body of its decision (the "half-effect" formula) and the course of the line $M-N$ specified in the dispositif and drawn on the Boundary-Line Chart. The basis of the United Kingdom's complaint is reflected in the following passages in Professor Briggs' dissenting opinion appended to the court's Decision of 14 March 1978 , supra note 7 , at 124 :

The Court's Expert was instructed to calculate the boundary-line on the basis of the above-mentioned determination of the Court [Decision (of June 30, 1977), supra note 7, paras. 248-54]; however, the Court did not appreciate that the boundary-line he depicted on a Mercator chart was a los:odrome which, over its course of about 170 nautical miles, disregarded the sphericity of the earth, instead of a geodesic conforming to the earth's curvature-a divergence not readily detectable to international lawyers from examination of the chart on which he drew the line.

The majority of the court held that:

[I]t has not been established that the course of the line M-N defined in the dispositif and traced on the Boundary-Line Chart is in such contradiction with the findings of the Court in paragraphs 251, 253 and 254 of the Decision of 30 June 1977 as to be incompatible with the method of delimitation prescribed in these findings.

Decision of 14 March 1978 , supra note 7 , para. 114, at 113.

This finding is as notable for what it does not say as for what it does, and a more candid account of the embarrassing position in which the court found itself is provided by the following passages in Professor Waldock's separate opinion, id. at 117:

I agree with the Court's conclusion that the information available does not appear to establish that the delimination of a maritime boundary by a loxodrome line on a standard navigational chart based on Mercator projection without correction for scale error is either inadmissible in law or so outmoded in practice as to make its use open, in general, to challenge. It is necessary, on the other hand, to consider the possible impact in this connection of the great extension seawards of the boundary in the present case, combined with the lateral relation of the coasts of the United King. dom and France in the Atlantic region. The Court, as it has recognised, made this combination of circumstances one of the cardinal elements in its decision to allow only half-effect to the Scilly Isles . . . .

Unfortunately, Professor Waldock felt, on balance, that a reconsideration along these lines was not open to the court under Article 10 of the Arbitration Agreement. He nevertheless expressed what to the present writer is the unassailable view that: "[I]f the matter were now to be open to reconsideration, I am of the opinion that the Court ought certainly to take account of the effect of the curvature of the earth on the operation of the equidistance principle over great distances such as those in the Atlantic region." Id. at 121.

It seems fair to conclude that, had the Court been aware of the implications of using the loxodrome method adopted by its Expert, it would in fact have used the 


\section{Conclusions}

Drawing together the various sections of part VI, what contribution has the decision of the Court of Arbitration made to the elucidation of the concept of special circumstances and of the relationship between Article 6 of the Geneva Convention and the corresponding rules of international customary law?

1. Relationship Between Article 6 and Rules of International Customary Law

It was concluded, on the basis of the analysis of "special circumstances" presented in section B, that this concept was much more limited in scope and less open to arbitrary and subjective concretisation than the principle of equity as interpreted by the I.C.J. in the North Sea Continental Shelf Cases, reviewed in section A. The Court of Arbitration would not appear to share this view and has gone a considerable way toward identifying "special circumstances" in the meaning of Article 6 with the equitable factors identified by the I.C.J. in the North Sea Cases. The conclusion was reached in section C(1) that, in Professor Briggs' words, the Court of Arbitration's interpretation of Article 6 "constitutes some threat that the rule of positive law expressed in Article 6 will be eroded by its identification with subjective equitable principles, permitting attempts by the Court to redress the inequities of geography."276

2. Status of Equidistance Rule and Burden of Proof of Special Circumstances

In section $\mathbf{C}(2)$, the opinion was expressed that a review of the travaux préparatoires of Article 6 indicates that the parties to the Geneva Convention intended the equidistance rule to be regarded as the general or residual rule and that the onus of proof lies upon those pleading special circumstances to prove their existence. It was concluded that the contrary view adopted by the court-that, strictly speaking, there is no burden of proof-is not only contrary to the intention of the parties but is open to the same objection as the court's view of the relationship between Article 6 and international customary law.

geodesic method. If this is so, it follows that the United Kingdom has been unjustly deprived of a significant area of continental shelf.

276. Decision, supra note 7, at 236 (declaration of Mr. H.W. Briggs). 
3. No Legal Limit to Considerations Which May Be Taken into Account to Ensure the Application of Equitable Principles

The court's restrictive interpretation of this somewhat ambiguous dictum from the I.C.J.'s judgment will, it may be hoped, dis* courage States from reading it too literally and from invoking as equitable considerations matters that, in law, clearly cannot properly be so considered.

\section{Proportionality Factor}

Section C(4) concluded that the Court of Arbitration's reinterpretation of the significance of the so-called proportionality factor has placed it in its proper perspective. The court's reinterpretation established that the factor is simply a criterion that may be called in aid to determine whether a particular geographical feature does constitute special circumstances because of its unjust distorting effects.

\section{Opposite-State and Adjacent-State Situations}

There are many situations in the world where the coasts of neighbouring States are not clearly classifiable as either opposite or adjacent. The court's sensible and practicable interpretation of Article 6 will facilitate its application in such cases.

\section{Islands and Archipelagos as Special Circumstances}

On the basis of an examination of the court's treatment of the archipelagos of the Channel Islands and of the Scilly Isles, it seems reasonable to conclude that less than justice was done to the United Kingdom. In relation to the Channel Islands, the court's decision seems difficult to justify either in terms of the application of the special circumstances rule to a substantial group of islands or in terms of a comparison with its treatment of the Scilly Isles. As regards the Scillies, the half-effect formula appears to be justifiable in principle but its application by the court is open to serious criticism.

\section{Macrogeographical Perspectives and the Court's COMPETENCE}

In the North Sea Continental Shelf Cases, the I.C.J. had to delimit the continental shelf areas appertaining to three neighbouring States-a situation that, in the view of the I.C.J., was "never really envisaged or taken into account" in the drafting of Article 6 
of the Geneva Convention.277 In dealing with this situation, the I.C.J. took the view that "given a geographical situation of quasiequality"-in the length of the coastal frontages of the three States-it was necessary to abate the effects of an incidental special feature (the concavity of the German coast) from which an unjustifiable difference of treatment could result.278 In other words, strict application of the equidistance principle would be unjustifiable because it would not bring about the results to be expected from application of the quasi-equality doctrine: that is, reasonable proportionality between length of coastal frontage and area of continental shelf.

As noted above,279 adoption of this quasi-equality/ proportionality test involved acceptance of the so-called "macrogeographical perspective." Thus, calculation of reasonable proportionality of the continental shelves of States $A$ and $B$ by reference to coastal frontage may require a consideration of the shelf of State $C$, for it is only by reference to State $B$ 's boundary with State $C$ that the area of State $B$ 's continental shelf may be calculated. As suggested above,280 there seems to be no justification for asserting the relevance of the boundary between States $B$ and $C$ to delimitation of the boundary between $A$ and $B$. In a case between $A$ and $B$, is State $C$ to be bound by the frontier between it and $B$ that the court used as a basis for application of the proportionality rule? One might ask, too, what the I.C.J.'s attitude would have been if only the Danish-German boundary dispute had been referred to it and not also the German-Netherlands boundary. Would the court still have adopted a three-State macrogeographical perspective? That it would have done is suggested by the fact that, in ensuring a reasonable degree of proportionality between length of coasts and areas of continental shelf, the court held that account was to be taken "of the effects, actual or prospective, of any other continental shelf delimitations between adjacent States in the same region." 281

A similar question was raised in the Anglo-French Case by the United Kingdom contention that, in assessing what would be an equitable delimitation between itself and France, account should

277. [1969] I.C.J. 3, para. 54.

278. Id. paras. 89-91.

279. See text accompanying note 216 supra.

280. Id.

281. [1969] I.C.J. 3, para. 101 (emphasis added). 
be taken of "the effects, actual or prospective, of any other continental shelf delimitations between adjacent States in the same region."282 The court was invited to consider the analogy between the situation of the United Kingdom, as the middle State compressed between the French and Irish areas of continental shelf, and that of Germany, caught between Denmark and the Netherlands.

The court was able to dispose of this argument simply by emphasising

that the task entrusted to it in the Atlantic region by the Arbitration Agreement is the precise one of deciding the course of the boundary between the portions of the continental shelf appertaining to the United Kingdom and to the French Republic respectively as far as the 1,000-metre isobath. 283

\section{It went on, however, to say that:}

Furthermore, as will subsequently appear in paragraph 250 of the Decision, the Court does not consider that the course of the boundary between the United Kingdom and the French Republic in that region depends on any nice calculations of proportionality based on conjectures as to the course of a prospective boundary between the United Kingdom and the Republic of Ireland. Nor would it be open to the Court, on the basis of any such conjectures, to pronounce in these proceedings on the position of the tripoint, if any, at which the Irish Republic's boundary with the United Kingdom should be held to meet the latter's boundary with the French Republic.284

The court left no shadow of doubt about the relationship between its decision and the boundary still to be determined between the United Kingdom and Ireland. The court thought it appropriate

formally to state that both its reasoning and its conclusions in this Decision are directed exclusively to the delimitation of the continental shelf boundary between the Parties to the present proceedings. It follows that no inferences may be drawn from this Decision as to views of the Court concerning the prospective course of the continental shelf boundary still to be delimited between the United Kingdom and the Republic of Ireland nor concerning the legal and factual considerations relevant to the delimitation of that boundary. The Court's Decision, it scarcely needs to be said, will be binding only as between the Parties to the present arbitration and will neither be binding upon nor create any rights or obligations for any third State, and in particular for the Republic of Ireland for which the Decision will be res inter alios acta. In so far as there may be a possibility that the two successive delimitations of continental shelf zones in this region, where the three States are neighbours abutting on the same continental shelf, may result in some overlapping of the zones, it is manifestly outside the competence of this Court to decide in advance and hypothetically the legal problem which may then arise. That problem would normally find its appropriate solution by negotiations directly between the three States concerned, negotiations which may indeed be called for by the prolongation of their maritime zones beyond the 1,000-metre isobath to

282. Decision, supra note 7, para. 24.

283. Id. para. 27.

284. Id. 
200 nautical miles. ${ }^{285}$

Whether there will be any such problem should become apparent relatively soon. The United Kingdom informed the court that, on February 18, 1977, it had addressed a Note to the government of the Irish Republic accepting the latter's proposal of April 2, 1976 , to refer the delimitation of the continental shelf as between their two countries to an independent settlement-of-disputes procedure through some form of third-party settlement of a judicial nature. 286

\section{The Status of the UNCLOS III Negotiating TeXtS}

The status of draft Articles produced by UNCLOS III has been considered twice by international judicial bodies within the past five years. In 1974, in the Fisheries Jurisdiction Case between the United Kingdom and Iceland, the I.C.J. referred to its awareness "of present endeavours . . . to achieve in a third Conference on the Law of the Sea the further codification and progressive development of this branch of the law" and of "various proposals and preparatory documents produced in this framework, which must be regarded as manifestations of the views and opinions of individual States and as vehicles of their aspirations, rather than as expressing principles of existing law."287 It held that "in the circumstances, the Court, as a court of law, cannot render judgment sub specie legis ferendae, or anticipate the law before the legislator has laid it down."288

As has been seen, the same question arose three years later in the Anglo-French Continental Shelf Case, France having argued that the Geneva Convention on the Continental Shelf had been rendered obsolete by a series of developments, including the UNCLOS III proceedings.289 The Court of Arbitration, in rejecting this contention, said that "only the most conclusive indications of the intention of the parties to the 1958 Convention to regard it as terminated could warrant this Court in treating it as obsolete and inapplicable as between" the parties.290 The court did examine

285. Id. para. 28.

286. Id. para. 26

287. Fisheries Jurisdiction Case, [1974] I.C.J. 3, para. 53.

288. Id.

289. Decision, supra note 7 , at 20 .

290. Id. para. 47. 
Article 71 of the Revised Single Negotiating Text (RSNT), 291 the earlier version of Article 83 of the Informal Composite Negotiating Text (ICNT), ${ }^{292}$ but was careful to mention that it had not yet been adopted by the Conference and was still a matter of discussion.293

At the present time (February, 1979), Article 83 of the ICNT is still a matter of discussion and has no legal force as a treaty provision. It cannot be said as yet to have reached that point of maturity at which it might be possible to say, by virtue of its clearly demonstrated general acceptability as a rule of customary law, that it "evidence[s] the assent of the States concerned to the modification, or even termination, of previously existing treaty rights and obligations." 294 The present unstable state of the Article is indicated by a passage in the Report of the chairman of Negotiating Group 7 of Committee II on the work of the Group during the first part of UNCLOS III's Seventh Session (Geneva, 28 March to 19 May 1978).295 Commenting on Article 83 (1), the chairman reported that:

\begin{abstract}
Like before, the positions of the delegations differed markedly between those in support of the equidistance solution and those favouring delimitation in accordance with equitable principles. The main proposals on this basic issue are contained in working documents NG7/2, sponsored by 22 States advocating the employment of the median or equidistance line as a general principle, and NG7/10, sponsored by 29 States emphasizing equitable principles as the basic premise for any measures of delimitation. No compromise on this point did materialize during the discussions held, although one may note, that there appears to be general agreement as regards two of the various elements of delimitation: first, consensus seems to prevail to the effect that any measure of delimitation should be effected by agreement, and second, all the proposals presented refer to relevant or special circumstances as factors to be taken into account in the process of delimitation. As a whole, however, no approach or formulation received such widespread and substantial support that would offer a substantially improved prospect of a consensus in the Plenary. On the other hand, the discussions clearly indicated that consensus could not, either, be reached upon the present formulation in the ICNT.296
\end{abstract}

He concluded that: "There was a general feeling within the Group that negotiations on the delimitation problems concerned should be continued at a later stage of the Conference and that

291. U.N. Doc. A/Conf. 62/WP. 8/Rev. 1, reprinted in 5 UNCLOS III OR 125 (1976).

292. U.N. Docs. A/Conf. 62/WP. 10 \& Add. 1, reprinted in 8 UNCLOS III OR 1 , and in 16 INT'L Legal Materials 1099 (1977).

293. Decision, supra note 7 , para. 96.

294. Id. para. 47.

295. UNCLOS III, Reports of the Committees and Negotiating Groups on negotiations at the Seventh Session contained in a single document both for the purposes of record and for the convenience of delegations, U.N. Doc. A/Conf. 62/RCNG/1, reprinted in 10 UNCLOS III OR 13 (1978).

296. Id. at 124. 
the rules of delimitation and the settlement of disputes thereon should not be separated from each other."297 Nor was any signifcant progress made during the second part of the Seventh Session (New York, August 21 to September 15, 1978).298

As was noted above, despite the embryonic nature of Article 71 of the RSNT, the Court of Arbitration did examine this provision, which is virtually identical to Article 83 of the ICNT. It is of some interest to note that the court found

no reason to suppose that, if they [the provisions of RSNT] were applicable, they would make any difference to the determination of the course of the boundary in the present case. Those texts speak of delimitation between "adjacent" or "opposite" States in accordance with equitable principles as distinct cases; and they envisage that, where appropriate, the equidistance or median line shall be employed, taking account of all the relevant circumstances. Since it is the geographical circumstances which primarily determine the appropriateness of the equidistance or any other method of delimitation in any given case, the Revised Single Negotiating Text would not appear to visualise the solution of cases like the present one on principles materially different from those applicable under the 1958 Convention or under general international law.299

As was seen in part V, the writer's interpretation of "special circumstances" in Article 6 of the Geneva Convention is somewhat narrower than that of the Court of Arbitration. It may be questioned, therefore, whether it is appropriate to regard the formula in Article 83 of the ICNT as being to the same effect as that in Article 6 of the Geneva Convention. As the following parallel texts show, the language of Article 83 follows very closely the language of the judgment of the I.C.J. in the North Sea Continental Shelf Cases, though it drops the court's reference to "natural prolongation":

297. Id. at 125.

298. See Report by the Chairman of Negotiating Group 7 on the work of the Group at its 17th-27th meetings, U.N. Doc. A/Conf. 62/C.2/NG7/24, reprinted in 10 UNCLOS III OR 170 (1978).

299. Decision, supra note 7, para. 96. 
I.C.J. Judgment in North Sea Continental Shelf Cases Para.

101(C)(1):

delimitation is to be effected by agreement in accordance with equitable principles, and taking account of all the relevant circumstances, in such a way as to leave as much as possible to each Party all those parts of the continental shelf that constitute a natural prolongation of its land territory into and under the sea, without encroachment on the natural prolongation of the land territory of the other.
ICNT

Article 83 (1)

The delimitation of the continental shelf between adjacent or opposite States shall be effected by agreement in accordance with equitable principles, employing, where appropriate, the median or equidistance line, and taking account of all the relevant circumstances.

As suggested above, 300 the formula adopted by the I.C.J. is much more open to subjective, arbitrary concretisation than are the terms of Article 6 of the Geneva Convention. The application of Article 83 of the ICNT might allow account to be taken of a number of factors that would not properly fall to be considered as potential special circumstances under Article 6 of the Geneva Convention.

\section{The Significance of the Decision}

If only because it is the second continental shelf boundary dispute to be settled by judicial means and the first between parties to the Geneva Convention on the Continental Shelf, the AngloFrench Case will certainly be studied very closely by those whose task it is to negotiate the settlement of other outstanding boundary disputes. Reference has already been made to the Anglo-Irish boundary and to the Rockall dispute. In view of certain similarities between the issues raised by the Anglo-French Case on the one hand and those presented by the Greco-Turkish dispute in the Aegean and by the United States-Canadian dispute in the Gulf of Maine on the other hand, the decision will clearly influence the negotiating stance and legal arguments of those countries.

How influential the decision will prove to be will depend in part on the outcome of UNCLOS III. If, contrary to present indications, a clear, workable formula is devised for the delimitation of the continental shelf between neighbouring States, the decision may prove to be of only transitional importance. Even in that

300. See text accompanying note 110 supra. 
event, however, it is likely to be some considerable time before the new convention comes into force. It was not, after all, until 1964 that the much more simple 1958 Convention entered into force, Even now only fifty-three States are bound by it.

Reviewing the analysis presented in parts II-VIII above, it seems likely that the principal contributions the decision will make to the law of the continental shelf will be:

1. In general, the decision has toned down and put a welcome moderating gloss on many of the dicta of the I.C.J. in the North Sea Cases.

2. The decision has helped to clarify the relationship between the Geneva Convention and international customary law.301 In doing so, the court has taken a position that enabled it to emphasize on the one hand that pacta sunt servanda is still a basic principle of treaty law, while acknowledging on the other hand that consensual obligations may under certain conditions be modified or terminated by developments in customary law. The status in this context of developments in UNCLOS III has been carefully stated, following the line taken by the I.C.J. in the North Sea Cases. ${ }^{302}$

3. The decision will help to dispose of the fallacious notion, fostered by the I.C.J.'s judgment in the North Sea Cases, that the concept of natural prolongation is of major relevance to the delimitation of the continental shelf between neighbouring States. ${ }^{303}$

4. The value of the court's contribution to the elucidation of the concept of special circumstances and of the relationship between Article 6 of the Geneva Convention and the corresponding rules of international customary law is less clear. ${ }^{304}$ The court has certainly performed a useful service in restrictively reinterpreting the I.C.J.'s dicta on the "proportionality factor" and on there being no legal limit to the considerations that may be taken into account to ensure the application of equitable principles. Again, the court's common-sense approach to geographical configurations that are neither opposite-coast nor adjacent-coast situtations will surely obviate much legalistic argument in relation to other such situations. However, it is regrettable that the

301. See pt. III supra.

302. See also pt. VIII supra.

303. See pt. V supra.

304. See the list of conclusions at pt. VI(D) supra. 
court saw fit to go as far as it did toward identifying "special circumstances" in the meaning of Article 6 of the Geneva Convention with the equitable factors identified by the I.C.J. in the North Sea Cases. Nor would it appear that the court's view of the status of the equidistance rule and of the burden of proof of special circumstances is well-founded.

5. Finally, the court's firm refusal to adopt a macrogeographical perspective and to have regard to a prospective Anglo-Irish boundary in determining the Anglo-French boundary should help to ensure that this undesirable doctrine is buried once and for all. 305

305. See pt. VII supra. 